\title{
Title: THERMAL ANALYSIS OF THE DRYWELL FOR THE NUCLEAR MATERIAL STORAGE FACILITY
}

\author{
Author(s): | Robert G. Steinke
}

\section{Submitted to: | WarrenWood}

\author{
DISCLAIMER
}

This report was prepared as an account of work sponsored by an agency of the United States Government. Neither the United States Government nor any agency thereof, nor any of their employees, makes any warranty, express or implied, or assumes any legal liability or responsibility for the accuracy, completeness, or usefulness of any information, apparatus, product, or process disclosed, or represents that its use would not infringe privately owned rights. Reference herein to any specific commercial product, process, or service by trade name, trademark, manufacturer, or otherwise does not necessarily constitute or imply its endorsement, recommendation, or favoring by the United States Government or any agency thereof. The views and opinions of authors expressed herein do not nesessarily state or reflect those of the United States Government or any agency thereof.

\section{Los Alamos}

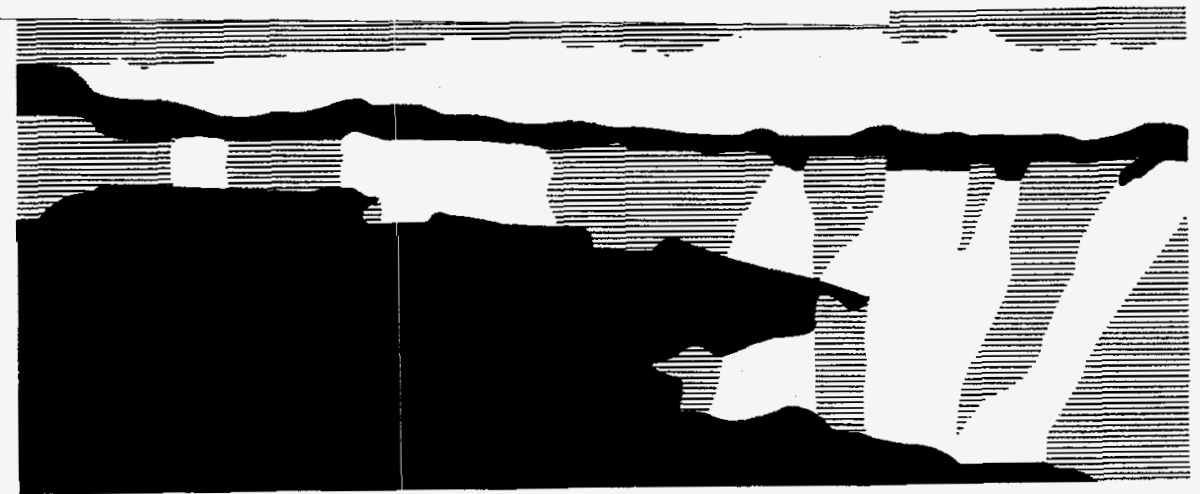

NATIONAL LABORATORY

Los Alamos National Laboratony, an affirmative action/equal opportunity empldyer, is operated by the University of California for the U.S. Department of Energy under contract W-7405-ENG-36. By acceptance of this article, the publisher recognizes that the U.S. Government retains a nonexclusive, royalty-free license to publish or reproduce the published form of this contribution, or to allow others to do so, for U.S. Government purposes. The Los Alamos National Laboratory requests that the publisher identify this article as work performed under the auspices of the U.S. Department of Energy. 


\section{DISClaAMER}

Portions of this document may be illegible in electronic image products. Images are produced from the best available original document. 


\title{
THERMAL ANALYSIS OF THE DRYWELL FOR THE NUCLEAR MATERIAL STORAGE FACILITY
}

by

\author{
Robert G. Steinke
}

\begin{abstract}
The Nuclear Material Storage Facility Renovation Project has a conceptual design for the facility to store nuclear materials in containers inside drywells with passive cooling for long-term storage. The CFX thermal-hydraulic computer program was used to analyze internal heat-transfer processes by conduction, convection, and radiation with natural circulation of air by hydraulic buoyancy with turbulence and thermal stratification (TS) evaluated. A vertical drywell was modeled with 14 containers on support plates at 12-in. intervals. The TS of bay air outside the drywell increased the container maximum temperature by $0.728^{\circ} \mathrm{F}$ for each $1.0^{\circ} \mathrm{F}$ of bay-air TS from the bottom to the top of the drywell. The clrywell outer-surface peak heat flux was shifted downward because of the effect of bay-air TS. An "equivalent" model was evaluated by the nodal-network conduction, convection, and radiation heat-transfer computer program (Thermal System Analysis Program) TSAP. The TSAP results are in good agreement with the CFX-model results, with the difference in results understood based on the approximations of each model.
\end{abstract}

\section{INTRODUCTION}

The conceptual design for the Nuclear Material Storage Facility (NMSF) renovation is based on passive, natural convection of air to remove the alpha decay heat generated by the stored plutonium. Temperature limits have been established for the stored materials for bounding operating conditions and design-basis events. ${ }^{1}$ Thermal analyses ${ }^{2-7}$ have shown that these temperature limits can be met by the conceptual design. These analyses were based on a Thermal System Analysis Program (TSAP) nodal-network, finite-difference model ${ }^{8}$ to evaluate heat transfer from the plutonium-helium mixture by conduction, convection, and radiation through the mixture container, helium gap, boundary container, air gap, storage pipe, another air gap, and drywell pipe to the bay air outside the drywell. (Plutonium and helium are separate materials within the container but are mixed together in the TSAP models.) The bay-air temperature and flow boundary conditions were based on NMSF thermal analyses using both a TSAP computer code model $^{9}$ and a CFX finite-difference, hydraulic-convection model. ${ }^{10}$ 
In all the TSAP models, heat transfer by convection between gas volume nodes is approximated by conduction with an enhanced thermal conductivity for the gas. CFX evaluates this correctly by solving the mass, momentum, and energy conservation equations directly. This means that the effects of hydraulic buoyancy, convection heat transfer, turbulence, and therrnal stratification (TS) are evaluated by CFX but are not evaluated by TSAP. When convection is toward a higher gas temperature, TSAP approximates convection heat transfer in the opposite (wrong) direction. TSAP can provide an accurate heat-transfer model only as long as these effects on heat transfer are small.

The current NMSF conceptual design for drywell storage has a column of containers on support plates within a steel-mesh, storage-cage pipe, as shown in Fig. 1. All of the storage-cage dimensions are preliminary at this time. The storage-cage pipe is located within the drywell pipe. This model $^{5}$ was evaluated by TSAP for different storage-cage materials (carbon steel or stainless steel) and radiation emissivities $(0.3$ to 0.92 ) to determine plutonium-helium-mixture maximum temperatures ranging from 140.0 to $155.4^{\circ} \mathrm{F}\left(62.8\right.$ to $\left.68.6^{\circ} \mathrm{C}\right)$ for an $80.0^{\circ} \mathrm{F}\left(26.7^{\circ} \mathrm{C}\right)$ bay-air temperature boundary condition. For the model, we assumed an axially repeated lattice of containers having the same thermal condition. This implies that the naturalconvection heat transfer is local to each container.

The major air-flow pattern within the drywell pipe is expected to be over the entire vertical length of the drywell pipe because the containers and storage cage are hotter than the drywell pipe and because the wire-mesh storage cage and its solid support plates are of a lesser diameter than the drywell pipe. The open wire mesh of the storage cage should allow the major air-flow pattern to affect other containers up the drywell as well. Locally, that natural-convection air flow behaves like forced convection because it is driven by the accumulated effect of the buoyancy-driven, natural convection of air by heat transfer from each container.

Surface-to-air, air-to-air, and air-to-surface convection heat transfer is enhanced by the higher air velocity of forced-convection-like flow. Heat from each of the containers accumulates in the air as it flows up the side of all the containers. This causes the top containers to be hotter because they are surrounded by hotter air than the bottom containers in the drywell pipe. The top containers will be even hotter when TS of the air both inside and outside the drywell pipe is accounted for in the model. The plutonium-helium mixture's maximum temperature is decreased by better convection heat transfer because of a higher air velocity, whereas it is increased by hotter air surrounding the top containers and the effect of air TS. We need to account for these effects if an accurate maximum temperature of the plutonium-helium mixture is to be predicted for the drywell conceptual design.

In this report, a CFX drywell model is analyzed to consider the effects of naturalconvection air flow and TS on heat transfer. An "equivalent" TSAP model for a single container is analyzed for comparison with the temperature results from the CFX model. 


\section{CFX MODEL}

A two-dimensional, thermal-hydraulic model of a drywell pipe and its contents was developed for analysis with the thermal-hydraulic computer program CFX. ${ }^{11}$ This analysis was done to evaluate air hydraulic convection and TS, as well as conduction, convection, and radiation heat transfer. CFX requires the coupled evaluation of two programs, CFX-F3D and CFX-RADIATION, to include radiation heat transfer. CFX-F3D is a general-purpose solver for hydraulic fluid flow and heat transfer based on the multiblock, finite-volume method. The modeling options used include incompressible buoyancy-driven flow, heat and mass transfer, conducting solids, and turbulence. CFX-RADIATION evaluates thermal-radiation heat fluxes by tracking photons through a set of radiation zones. The utility program CFX-MESHIMPORT is used to construct radiation zones as a collection of control volumes based on the geometry and mesh of the CFX-F3D region of solution.

The CFX model of an NMSF drywell is shown in Fig. 2. Fourteen containers, each producing $15 \mathrm{~W}$ of heat, are placed concentrically, one above another, at 12-in. intervals in the drywell pipe. Each container has a 5-in. o.d. and a 10-in. height. The drywell pipe is $0.5 \mathrm{in}$. thick, with an inner diameter of $17 \mathrm{in.}$ and an internal height of 175 in. This leaves an 8.75-in. air space above the top container. The axial ends of the drywell pipe are assumed to be closed and insulated; therefore, no-flow, adiabatic boundary conditions are applied to the ends. 'The containers are supported by 8 -in.diam, 0.5-in.-thick plates with a 0.25-in.-deep by 5.0-in.-diam cutout for concentrically positioning the bottom of the container in its plate. These plates are held in place by a steel wire-mesh storage cage, as shown in Fig. 1, that extends from the bottom to the top of the drywell pipe.

The storage-cage, wire-mesh structure and contact spring in Fig. 1 are not modeled in the current study. The plutonium-helium mixture, mixture container, and helium gap that are inside the boundary container also are not modeled because the container is assumed to be solid stainless steel. The $15 \mathrm{~W}$ of heat generated in the plutonium-helium mixture is assumed to be generated uniformly in the volume of the container and its plate. These approximations were made for ease in developing the CFX model and because our main interest is evaluating the effect of convective air flow and heat transfer on drywell temperature distribution.

Figure 3 shows the top portion of the axisymmetric computational mesh used for the analysis. The entire CFX model consists of 9576 cells. In general, the mesh resolution is finer near solid surfaces, where steep gradients in velocity and temperature are expected. Probably there should be even more mesh refinement because surface-to-air convection heat transfer through the air boundary layer is being evaluated using first principles-conduction and advection coupled to local temperature and velocity profiles. Probably more than two or three cell layers from the surface (as modeled) are needed to evaluate these profiles accurately. Six layers of cells were used to resolve the 1.75-in. air gap between the top of a container and the bottom of the support plate above it. 
Fluid flow is assumed to be incompressible, and buoyancy-driven circulation is modeled with the Boussinesq approximation. Because of the relatively large drywell height (where the characteristic length gives a large Grashof or Raleigh number), turbulent natural convection is expected to occur. Therefore, the k-epsilon turbulence model is applied. For conduction and radiation heat transfer, the container and support plate are assumed to be stainless steel with a thermal conductivity of $16.4 \mathrm{~W} \mathrm{~m}^{-1}{ }^{\circ} \mathrm{C}^{-1}\left(9.48 \mathrm{Btu} \mathrm{h}^{-1} \mathrm{ft}^{-1}{ }^{\circ} \mathrm{F}^{-1}\right)$ and a radiation emissivity of 0.3. The drywell pipe is assumed to be carbon steel with a thermal conductivity of $53.7 \mathrm{~W} \mathrm{~m}^{-1}{ }^{\circ} \mathrm{C}^{-1}\left(31.0 \mathrm{Btu} \mathrm{h}^{-1} \mathrm{ft}^{-1}{ }^{\circ} \mathrm{F}^{-1}\right)$ and a radiation emissivity of 0.8 .

CFX was used before to analyze heat removal from the NMSF by natural-convection air flow through the drywell bays of the facility. ${ }^{10}$ In that analysis, a uniform axial heat flux from the drywell outer surface was assumed. Rather than use the maximum TS of the bay air from the results of that model for the CFX drywell model, we have chosen to define a bay-air temperature boundary condition with linear variation axially. ${ }^{12}$ Three temperature boundary conditions are considered:

1. $\mathrm{T}(\mathrm{z})_{\text {bay air }}=80.0^{\circ} \mathrm{F}=26.7^{\circ} \mathrm{C}$ (no TS),

2. $\mathrm{T}(\mathrm{z})_{\text {bay }}$ air $=80.0^{\circ} \mathrm{F}+20.0^{\circ} \mathrm{F} \cdot(\mathrm{z} / \mathrm{Z})=26.7^{\circ} \mathrm{C}+11.1^{\circ} \mathrm{C} \cdot(\mathrm{z} / \mathrm{Z})$ (assumed nominal maximum TS), and

3. $\mathrm{T}(\mathrm{z})_{\text {bay air }}=80.0^{\circ} \mathrm{F}+40.0^{\circ} \mathrm{F} \cdot(\mathrm{z} / \mathrm{Z})=26.7^{\circ} \mathrm{C}+22.2^{\circ} \mathrm{C} \cdot(\mathrm{z} / \mathrm{Z})$ (assumed worstcase maximum TS),

where $0 \leq z \leq Z=175$ in. (the vertical length of the drywell pipe). Preliminary results from an analysis with the first boundary condition, $\mathrm{T}(\mathrm{z})$ bay air $=80.0^{\circ} \mathrm{F}$ $\left(26.7^{\circ} \mathrm{C}\right.$ ), have already been reported. 13 An improvement (discussed in the next paragraph) is made to that model for the present analysis of all three boundary conditions. As a follow-up to these calculations, the axial heat-flux profiles evaluated from boundary conditions 1 and 2 need to be interpolated appropriately and used to replace the uniform axial heat-flux assumption in the NMSF drywellbay analysis. 10 Redoing the NMSF drywell-bay analysis should then give bay-air axial temperature profiles that are consistent with those interpolated for the axial heat-flux profiles that are used. Consistency may require iterations between the CFX drywell and facility calculations and possibly a nonlinear axial variation for the second $\mathrm{T}(\mathrm{z})_{\text {bay air }}$ boundary condition.

Heat transfer from the outer surface of the drywell to the bay air requires a convection heat transfer coefficient (HTC) h, which is based on an appropriate $\mathrm{Nu}$, to define the boundary condition $T_{\text {surface }}=T_{\text {bay air }}+Q_{\text {heat-flux }} / \mathrm{h}$ for CFX. The preliminary analysis 13 assumed laminar-flow, natural convection from a single drywell pipe in an air medium, which gave an HTC of $h=2.0 \mathrm{~W} \mathrm{~m}^{-2}{ }^{\circ} \mathrm{C}^{-1}(0.35 \mathrm{Btu}$ $\left.\mathrm{h}^{-1} \mathrm{ft}^{-2}{ }^{\circ} \mathrm{F}^{-1}\right)$. A more appropriate assumption for the present analysis is to use the $\mathrm{Nu}$ correlation ${ }^{14}$

$$
\mathrm{Nu}=\mathrm{h} \cdot \mathrm{D} / \mathrm{k}=\mathrm{b} \cdot(\operatorname{Re})^{\mathrm{n}}=\mathrm{b} \cdot\left(\mathrm{D} \cdot \mathrm{G}_{\max } / \mu\right)^{\mathrm{n}}
$$


for forced convection, which is normal to banks of pipes where

$\mathrm{D}$ is the pipe's outer diameter, $\mathrm{k}$ is the gas thermal conductivity, $\mathrm{b}$ and $\mathbf{n}$ are correlation constants, Re is the Reynolds number,

$\mathrm{G}_{\max }=\mathrm{V}_{\max } \cdot \rho$ is the maximum mass flux at the minimum flow area between pipes,

$\mathrm{V}_{\max }$ is the maximum gas velocity at that minimum flow area,

$\rho$ is the gas density, and

$\mu$ is the gas viscosity.

Although air flow through the facility is by natural convection, air flow past the drywell pipes locally is similar to forced convection with maximum velocity $V_{\max }$. The $b$ and $n$ correlation constants are based on an assumed in-line square lattice of 18-in. o.d. drywell pipes having a 24-in. pitch. This gives interpolated values of $b=$ 0.3251 and $n=0.5973$ from tabular data. ${ }^{14}$ The hottest drywell pipe of interest is assumed to be at least 10 rows into the in-line square lattices of pipes from the airflow inlet. Using temperature-dependent air properties and $\mathrm{V}_{\max }=\mathrm{V}_{\infty} \cdot 4.0=$ $0.588 \mathrm{~m} \mathrm{~s}^{-1}\left(1.93 \mathrm{ft} \mathrm{s}^{-1}\right)$ from the facility analysis, $10 \mathrm{~h}=6.16 \mathrm{~W} \mathrm{~m}^{-2}{ }^{\circ} \mathrm{C}^{-1}\left(1.085 \mathrm{Btu} \mathrm{h}^{-1}\right.$ $\left.\mathrm{ft}^{-2}{ }^{\circ} \mathrm{F}^{-1}\right)$ at an air temperature of $80.0^{\circ} \mathrm{F}\left(26.7^{\circ} \mathrm{C}\right)$, and $\mathrm{h}=6.08 \mathrm{~W} \mathrm{~m}^{-2}{ }^{\circ} \mathrm{C}^{-1}$ $\left(1.071 \mathrm{Btu} \mathrm{h}^{-1} \mathrm{ft}^{-2}{ }^{\circ} \mathrm{F}^{-1}\right)$ at an air temperature of $100.0^{\circ} \mathrm{F}\left(37.8^{\circ} \mathrm{C}\right)$. The database for this correlation is for pipe diameters $\leq 5.0 \mathrm{in}$., and the correlation fit to that data has an average deviation of $\pm 5 \%\left( \pm 0.3 \mathrm{~W} \mathrm{~m}^{-2}{ }^{\circ} \mathrm{C}^{-1}\right)$. Because of this uncertainty, $\mathrm{h}=6.15 \mathrm{~W}$ $\mathrm{m}^{-2}{ }^{\circ} \mathrm{C}^{-1}\left(1.083 \mathrm{Btu} \mathrm{h}^{-1} \mathrm{ft}^{-2}{ }^{\circ} \mathrm{F}^{-1}\right)$ is used for all bay-air temperatures. This $\mathrm{HTC}_{\overline{;}}$ three times larger than in the preliminary analysis, reduced the temperature difference between the drywell outer surface and bay air by a factor of 0.325 from that of the preliminary analysis.

\section{CFX RESULTS}

Each of the three different CFX steady-state calculations was evaluated with an initial constant temperature-distribution estimate of $26.667^{\circ} \mathrm{C}\left(80.0^{\circ} \mathrm{F}\right)$ and an initial air velocity of zero everywhere in the region of solution. Each calculation was evaluated overnight on a SUN SPARCstation 20 computer for 4000 iterations. The rate of change of the temperature distribution decreased during the first 1000 iterations and oscillated a small amount without further reduction for the remaining 3000 iterations. We judged that steady-state convergence of the solution was achieved after 1000 iterations.

Figures $4 \mathrm{a}, 4 \mathrm{~b}$, and $4 \mathrm{c}$ show the calculated air velocity-vector distributions within the entire drywell pipe (shown in five axial sections) from each of the three steady-state calculations. Air circulates from the bottom to the top of the drywell, with air flowing up along the side of the containers and their plates while being heated and flowing down along the inner surface of the drywell while being cooled. A double counter-rotating eddy flow pattern occurs in the air space between the top of each 
container and the bottom of the support plate above it. There is only a single counter-rotating eddy flow pattern above the top (fourteenth) container. With air flow around each plate, a small part (a few percent) of that flow appears to cross over (taking a short cut from the full-circulation pattern) and flow down the inner surface of the drywell. Flow stagnation regions can be observed in the air space above each container, at the corner between al container and its support plate, and midway between the radial side of each container and the drywell. Visually, there is little difference in the velocity-vector patterns from the three calculations. The maximum air velocity (at the radial side of each container near its top) decreases slightly with increased bay-air TS:

- $0.179 \mathrm{~m} \mathrm{~s}^{-1}\left(0.587 \mathrm{ft} \mathrm{s}^{-1}\right)$ with no TS,

- $0.174 \mathrm{~m} \mathrm{~s}^{-1}\left(0.571 \mathrm{ft} \mathrm{s}^{-1}\right)$ with $20.0^{\circ} \mathrm{F}\left(11.1^{\circ} \mathrm{C}\right) \mathrm{TS}$, and

- $0.170 \mathrm{~m} \mathrm{~s}^{-1}\left(0.558 \mathrm{ft} \mathrm{s}^{-1}\right)$ with $40.0^{\circ} \mathrm{F}\left(22.2^{\circ} \mathrm{C}\right) \mathrm{TS}$,

where the TS temperature increase is from the bottom to the top of the drywell.

Figures $5 a, 5 b$, and $5 c$ show the calculated temperature distributions within the entire drywell pipe (shown in five axial sections) from each of the three steady-state calculations. As expected, the container's maximum temperature increases significantly with increased TS:

- $125.0^{\circ} \mathrm{F}\left(51.7^{\circ} \mathrm{C}, 324.8 \mathrm{~K}\right)$ with no $\mathrm{TS}$,

- $139.5^{\circ} \mathrm{F}\left(59.8^{\circ} \mathrm{C}, 333.0 \mathrm{~K}\right)$ with $20.0^{\circ} \mathrm{F}\left(11.1^{\circ} \mathrm{C}\right) \mathrm{TS}$, and

- $154.1^{\circ} \mathrm{F}\left(67.8^{\circ} \mathrm{C}, 341.0 \mathrm{~K}\right)$ with $40.0^{\circ} \mathrm{F}\left(22.2^{\circ} \mathrm{C}\right) \mathrm{TS}$.

For each $1.0^{\circ} \mathrm{F}\left(0.555^{\circ} \mathrm{C}\right)$ of TS, the container maximum temperature increases by $0.728^{\circ} \mathrm{F}\left(0.404^{\circ} \mathrm{C}\right)$. The coolest temperature at the bottom of the drywell also increases with TS from $86.5^{\circ} \mathrm{F}\left(30.3^{\circ} \mathrm{C}, 303.4 \mathrm{~K}\right)$ with no TS to $89.1^{\circ} \mathrm{F}\left(31.7^{\circ} \mathrm{C}, 304.9 \mathrm{~K}\right)$ with $20.0^{\circ} \mathrm{F}\left(11.1^{\circ} \mathrm{C}\right) \mathrm{TS}$ and $92.1^{\circ} \mathrm{F}\left(33.4^{\circ} \mathrm{C}, 306.5 \mathrm{~K}\right)$ with $40.0^{\circ} \mathrm{F}\left(22.2^{\circ} \mathrm{C}\right)$ TS from the bottom to the top of the drywell. This temperature increase is due to more heat loss from the bottom of the drywell pipe to the bay air with increased TS. Fifty-four shades of color in the temperature contours of Figs. $5 a, 5 b$, and $5 c$ give a detailed presentation of the air temperature distribution. The detail is less in the container, plate, and drywell because their temperatures are more constant because of their high thermal conductivity.

For a more quantitative presentation of the temperature results, axial and radial temperature profiles are shown in Figs. 6 and 7, respectively, for each of the three boundary-condition steady-state calculations. The axial temperature profiles are at the radial positions of the following:

1. near container centerline ( $r=0.156$ in.),

2. container radial-surface air and plate $(r=2.875$ in.),

3. air radially midway between the container and drywell $(r=5.968 \mathrm{in}$.$) ,$ 
4. drywell inner-surface air $(r=8.387$ in. $)$,

5. drywell near its outer surface $(r=8.875$ in.), and

6. drywell outer-surface bay-air boundary condition $(r=9.5$ in).

The radial temperature profiles are near the axial-center positions of the following:

1. first (bottom) container $(z=5.847$ in.),

2. fifth container $(z=53.847$ in. $)$,

3. ninth container $(z=101.847$ in.),

4. fourteenth (top) container ( $\mathrm{z}=161.847 \mathrm{in}$.), and

5. air above the fourteenth container $(z=171.173$ in. $)$.

With no TS, the sixth-to-fourteenth containers have approximately the same maximum temperature of $125.0^{\circ} \mathrm{F}\left(51.7^{\circ} \mathrm{C}\right)$. This is shown by the same red temperature of these containers in Fig. $5 \mathrm{a}$ and in the lower plot of Fig. 6. With TS, the containers get progressively hotter at higher axial locations. The container's maximum temperature increases by $0.728^{\circ} \mathrm{F}\left(0.404^{\circ} \mathrm{C}\right)$ for each $1.0^{\circ} \mathrm{F}\left(0.555^{\circ} \mathrm{C}\right)$ of TS (as discussed in the previous paragraph). This corresponds to container maximum temperatures of $139.6^{\circ} \mathrm{F}\left(59.8^{\circ} \mathrm{C}\right)$ with a TS of $20.0^{\circ} \mathrm{F}\left(11.1^{\circ} \mathrm{C}\right)$ and of $154.1^{\circ} \mathrm{F}\left(67.8^{\circ} \mathrm{C}\right)$ with a TS of $40.0^{\circ} \mathrm{F}\left(22.2^{\circ} \mathrm{C}\right)$, as shown in Figs. 6 and 7. The thirteenth container is the hottest with no TS, whereas the fourteenth container is the hottest with TS. The cooler air and no hot support plate above the fourteenth container keeps the container cooler with no TS. Keep in mind that the container's maximum temperature is not the maximum temperature of the plutonium-helium mixture because the container is assumed to be solid stainless steel in this model.

The amount of bay TS depends on the flow distribution and the axial heat-flux profiles from the outer surface of the drywell pipes. Axial heat-flux profiles from the three calculations are shown in Fig. 8 for the inner and outer surfaces of the drywell. The three outer-surface, axial, heat-flux profiles are shown again in the single plot of Fig. 9. As might be expected, the effect of TS is to decrease the outersurface heat flux at the top of the drywell and increase it at the bottom of the drywell because TS reduces the temperature difference between the outer surface and the bay air at higher axial locations. Radiation heat transfer directly from the container and plate surface to the inner surface of the drywell causes the inner-surface heat flux to peak near the axial midpoint of each container. The axial variation is not smooth because of the default number of rays used to track photons through the set of radiation zones. More rays need to be tracked for the level of zone (mesh) refinement in the model to provide a smoother axial heat-flux profile at the inner surface of the drywell. The inner-surface heat flux generally exceeds the outersurface heat flux, except at the bottom and top ends of the drywell pipe. Heat is conducted axially from the central region of the drywell pipe to its ends to accomplish this axial heat-flux profile change from the inner to the outer surface of the drywell. The axial conduction of heat by the drywell pipe (from the three calculations) is shown in Fig. 10. All of that heat-flux difference is conducted to the bottom of the drywell pipe for the two cases of 'TS.

In the next section, an "equivalent" TSAP model is analyzed to compare its temperature results with those of the CFX model. Consistency of results is expected, 
and any significant difference will need to be explained on the basis of their modeling differences. Confidence in the predictive ability of each model is based on building a database of such comparisons and understanding the levels of error associated with each model's approximations. Figures 11 and 12 show the radial and axial temperature profiles of the hottest (thirteenth) container in the CFX model with a constant $80.0^{\circ} \mathrm{F}\left(26.7^{\circ} \mathrm{C}\right)$ bay-air temperature boundary condition. The axial [with 0.25 in. $+(12$ in. $\times 12)=144.25$ in. subtracted] and radial locations, respectively, of these temperature profiles are as close as possible to the axial and radial locations of the temperature profiles from the TSAP model that will be shown later for comparison. The hottest container from the CFX model is chosen for comparison with the average container of the TSAP model because we are interested in predicting worst-case conditions. For "equivalence," the TSAP average container and the CFX hottest container both need to have the same $80.0^{\circ} \mathrm{F}\left(26.7^{\circ} \mathrm{C}\right)$ bay-air temperature boundary condition. The effect of TS can be superimposed on the TSAP average-container results by adding $0.728^{\circ} \mathrm{F}\left(0.404^{\circ} \mathrm{C}\right)$ to its container maximum temperature for each $1.0^{\circ} \mathrm{F}\left(0.556^{\circ} \mathrm{C}\right)$ of bay-air TS.

\section{TSAP MODEL}

A TSAP model for comparison with the CFX model is not available from the previous TSAP thermal analyses of the drywell pipe. ${ }^{2-5}$ The base model ${ }^{4}$ from that analysis will require:

1. eliminating the storage pipe,

2. reducing the axial spacing between containers from $18.0 \mathrm{in}$. to $12.0 \mathrm{in.}$

3. changing the plutonium-helium mixture volume in the inner container from $50 \%$ to $100 \%$,

4. modeling the support plate,

5. changing the plutonium-helium mixture, helium gap, and support plate to stainless steel with a thermal conductivity of $16.4 \mathrm{~W} \mathrm{~m}^{-1}{ }^{\circ} \mathrm{C}^{-1}(9.48 \mathrm{Btu}$ $\left.\mathrm{h}^{-1} \mathrm{ft}^{-1}{ }^{\circ} \mathrm{F}^{-1}\right)$, and

6. changing the $15-\mathrm{W}$ heat source from being uniform in the plutoniumhelium mixture to being uniform in the solid stainless-steel container and support plate.

The storage-cage model ${ }^{5}$ is closer to the CFX model because it does not require the changes of items 2 and 4; however, the input-data changes for item 1 involve more work than the changes of items 2 and 4 . Thus, a TSAP model "equivalent" to the CFX model has been based on making changes 2 through 6 to the base model without a storage pipe from Ref. 4. A diagram of that TSAP model is shown in Fig. 13. The plutonium-helium mixture and helium-gap regions have kept their identity to reverse the changes of items 5 and 6 for a final TSAP analysis where the solid stainless-steel container is remodeled realistically with the plutonium-helium mixture and the helium gap between containers. This is done to determine the 
change in the maximum temperature from stainless steel to the plutonium-helium mixture that would need to be added to the container maximum temperature from the CFX model to predict its plutonium-helium mixture's maximum temperature.

\section{TSAP RESULTS}

The "equivalent" TSAP radial and axial temperature profiles are shown in Figs. 14 and 15, respectively. For the most part, these results are similar to the CFX results in Figs. 11 and 12, respectively, except for the following local temperature differences:

1. The TSAP average temperature rise from the drywell inner surface to the adjacent air in Fig. 14 is $\sim 8.7^{\circ} \mathrm{F}$, compared with $\sim 7.9^{\circ} \mathrm{F}$ from the CFX model in Fig. 11. This temperature rise is because of the TSAP assumption that local air circulation by natural convection is based on a driving force caused by the local temperature difference between the surface and the air. The actual driving force is the hydraulic buoyancy of this accumulated effect over the entire drywell length. The resulting air flow down the side of the drywell is greater than that caused by local natural convection and is more like forced convection. This results in an HTC at the drywell inner surface that is $\sim 8.7^{\circ} \mathrm{F} / \sim 7.9^{\circ} \mathrm{F}=\sim 1.10$ times larger because of the higher air velocity.

2. The TSAP average temperature rise from the adjacent air to the radial surface of the container in Fig. 14 is $\sim 21.2^{\circ} \mathrm{F}$, compared with $\sim 19.6^{\circ} \mathrm{F}$ from the CFX model in Fig. 11. Again this is due to the TSAP assumption of local air circulation by natural convection based on a local surface-to-air temperature-difference driving force. The actual driving force is the hydraulic buoyancy of this accumulated effect from the heating of all 14 containers over the drywell length. The resulting air flow up the side of the container is greater than that caused by local natural convection and is more like forced convection. This results in a container radial HTC that is $\sim 21.2^{\circ} \mathrm{F} / \sim 19.6^{\circ} \mathrm{F}=\sim 1.08$ times larger because of the higher air velocity.

3. The radial temperature profile through the support plate (at $Z=11.85$ in. in Fig. 11 and at $Z=11.87$ in. in Fig. 14) from $R=1.25$ in. to $R=4.0$ in. gives an average temperature difference between the support-plate surface and the surrounding air of $\sim 2.6^{\circ} \mathrm{F}$ in Fig. 11 , compared with $\sim 18.2^{\circ} \mathrm{F}$ in Fig. 14 . The HTC from the support-plate surface to the adjacent air in the CFX model is $\sim 18.2^{\circ} \mathrm{F} / \sim 2.6^{\circ} \mathrm{F}=\sim 7.0$ times greater because of the large air velocity that follows the support-plate contour between the radial sides of the containers. This is especially true for the bottom surface of the support plate, where the TSAP Nu correlation is based on almost no natural circulation of the cooler air below a horizontal heated surface.

4. The air midway between the top of the container and the support plate above the container is $120.6^{\circ} \mathrm{F}\left(49.2^{\circ} \mathrm{C}\right), 117.8^{\circ} \mathrm{F}\left(47.7^{\circ} \mathrm{C}\right)$, and $115.9^{\circ} \mathrm{F}\left(46.6^{\circ} \mathrm{C}\right)$ in Fig. 12 from the CFX model and $111.9^{\circ} \mathrm{F}\left(44.4^{\circ} \mathrm{C}\right), 110.9^{\circ} \mathrm{F}\left(43.8^{\circ} \mathrm{C}\right)$, and $109.4^{\circ} \mathrm{F}\left(43.0^{\circ} \mathrm{C}\right)$ in Fig. 15 from the TSAP model. The air-flow pattern in the CFX model shows this region to have almost stagnant air, with a 
double counter-rotation eddy flow pattern. The normal-direction air flow at the radial edge of the container top prevents a larger natural-circulation air flow that otherwise would occur between these two heated surfaces. TSAP's Nu correlation for a heated surface below cooler air predicts a higher convection HTC than CFX does directly in this stagnant air region. However, more significant is TSAP's convection heat transfer (by air flow between air nodes above the container) being based on enhanced conduction with an assumed enhancement factor of 30 . The stagnant air condition determined by the CFX model justifies an order-of-magnitudesmaller enhancement factor in this local region. TSAP models too much convection heat transfer from the top of the container to the air of nodes 69 and 70 in Fig. 13 and then from these air nodes to the air of their radially adjacent nodes 70 and 71 .

The first two differences given above are small, whereas the last two differences are large in their local effect. With these differences, the container maximum temperature is $125.0^{\circ} \mathrm{F}\left(51.67^{\circ} \mathrm{C}\right)$ from the $\mathrm{CFX}$ model and $129.4^{\circ} \mathrm{F}\left(54.1^{\circ} \mathrm{C}\right)$ from the TSAP model. The less-accurate TSAP prediction is slightly high and conservative.

The following four adjustments have been made to the TSAP model to see if these temperature differences with the CFX model can be corrected in the TSAP model:

1. The HTC for natural-convection heat transfer from air to the drywell inner surface is increased by a factor of 1.10 .

2. The HTC for natural-convection heat transfer from the container radial side to air is increased by a factor of 1.08 .

3. The HTCs for natural-convection heat transfer from the support-plate surfaces of nodes 79, 80, and 81 in Fig. 13 are increased by a factor of 7.0.

4. The enhancement factor of 30 is reduced by an order of magnitude to 3 for enhanced conduction from air nodes 69 to 70 and 70 to 71 in Fig. 13.

The "adjusted" TSAP radial and axial temperature profiles are shown in Figs. 16 and 17 , respectively. The temperatures are in better agreement for the above four items. The CFX model still cools the support plate more than does the TSAP model. An adjustment factor of 15 to 20 rather than 7 probably is needed for the TSAP supportplate HTC to obtain better agreement. However, doing that may cause TSAP to overpredict axial heat transfer slightly in the container. With this adjusted TSAP model, the container maximum temperature is the same as from the CFX model, i.e., $125.1^{\circ} \mathrm{F}\left(51.72^{\circ} \mathrm{C}\right)$ from the TSAP model, compared with $125.0^{\circ} \mathrm{F}\left(51.67^{\circ} \mathrm{C}\right)$ from the CFX model.

As discussed earlier, this container's maximum temperature is less than the plutonium-helium mixture's maximum temperature because the thermal conductivity of the solid stainless-steel container $\left(16.4 \mathrm{~W} \mathrm{~m}^{-1}{ }^{\circ} \mathrm{C}^{-1}\right)$ is 19 times that of the $\mathrm{Pu} / \mathrm{He}$ gas $\left(0.863 \mathrm{~W} \mathrm{~m}^{-1}{ }^{\circ} \mathrm{C}^{-1}\right)$. The solid stainless-steel container also does not have the thermal resistance of the helium gas gap between the containers. To 
predict the plutonium-helium mixture's maximum temperature that the CFX model would have determined with a realistic container model, we will further modify the adjusted TSAP model to model

1. the plutonium-helium mixture in $100 \%$ of the mixture-container volume,

2. the 15-W heat-source generation only in the plutonium-helium mixture, and

3. the helium gap between the mixture and boundary containers.

This "realistic-container" TSAP model should predict the maximum temperature of a realistic-container CFX model because of the good agreement shown above with the adjusted TSAP model. The radial and axial temperature profiles determined are shown in Figs. 18 and 19, respectively. The plutonium-helium mixture's maximum temperature is $144.6^{\circ} \mathrm{F}\left(62.5^{\circ} \mathrm{C}\right)$ in node 33 of Fig. 13. This compares with a plutonium-helium mixture's maximum temperature of $155.4^{\circ} \mathrm{F}\left(68.6^{\circ} \mathrm{C}\right)$ when the wire-mesh storage cage, contact spring, and plutonium-helium mixture in $50 \%$ of the mixture-container volume were modeled before for a stainless-steel support plate and storage cage. ${ }^{5}$

\section{SUMMARY AND CONCLUSIONS}

Thermal-hydraulic conduction, convection, and radiation heat-transfer analyses of the NMSF drywell pipe were evaluated with the CFX computer program. ${ }^{11} \mathrm{~A}$ drywell pipe, containing 14 plutonium-helium mixture storage containers on support plates, was modeled. Each container was assumed to have a heat source of $15 \mathrm{~W}$. The purpose of this model was to evaluate the convective air flow and heat transfer between the hotter containers and their support plate and the cooler drywell pipe that surrounds them. Natural convection, hydraulic buoyancy, TS, and turbulence were involved in the evaluation. TS of the bay air outside the drywell pipe was modeled, with the air temperature boundary condition having linear variation axially. To reduce the developmental and computational effort, the wiremesh storage cage surrounding the containers (with attachment to the support plates) was not modeled. The internal structure of each container was neglected by assuming that the container is solid stainless steel with its $15-\mathrm{W}$ heat source generated uniformly in the combined volume of the container and its support plate.

The convective air-flow pattern was evaluated over the vertical length of the drywell. Air rises along the 2.5-in. radius side of each container (as it is heated) with surface-conforming flow around each 4.0-in. radius support plate. Only a small part of the air flow is diverted radially outward to the drywell by the bottom surface of each support plate. More air flow would be diverted to the drywell by each support plate if the storage cage were modeled and if the support-plate radius were increased toward the 8.5-in. inner radius of the drywell pipe. When the major flow reaches the closed-end top of the drywell pipe, it turns radially outward and down the inner surface of the drywell pipe while in the process losing its heat to the cooler drywell. At the closed-end bottom of the drywell pipe, the cooled air flows radially inward to 
repeat its flow up the radial surface of each container and support plate. Maximum air velocities of

1. $0.179 \mathrm{~m} \mathrm{~s}^{-1}\left(0.587 \mathrm{ft} \mathrm{s}^{-1}\right)$ with no TS,

2. $0.174 \mathrm{~m} \mathrm{~s}^{-1}\left(0.572 \mathrm{ft} \mathrm{s}^{-1}\right)$ with $20.0^{\circ} \mathrm{F}\left(11.1^{\circ} \mathrm{C}\right) \mathrm{TS}$, and

3. $0.170 \mathrm{~m} \mathrm{~s}^{-1}\left(0.558 \mathrm{ft} \mathrm{s}^{-1}\right)$ with $40.0^{\circ} \mathrm{F}\left(22.2^{\circ} \mathrm{C}\right) \mathrm{TS}$

were evaluated at the radial-side top of the topmost (fourteenth) container in the drywell.

With no TS of the bay air [defined by a constant $80.0^{\circ} \mathrm{F}\left(26.7^{\circ} \mathrm{C}\right)$ bay-air temperature boundary condition], the first five containers from the bottom of the drywell get progressively hotter, with maximum temperatures of $119.0^{\circ} \mathrm{F}\left(48.3^{\circ} \mathrm{C}\right)$ to $123.6^{\circ} \mathrm{F}$ $\left(50.9^{\circ} \mathrm{C}\right)$. The sixth through the fourteenth containers have almost the same maximum temperature of $124.0^{\circ} \mathrm{F}\left(51.1^{\circ} \mathrm{C}\right)$ to $125.0^{\circ} \mathrm{F}\left(51.7^{\circ} \mathrm{C}\right)$, with the thirteenth container being the hottest. Bay TSs of $20.0^{\circ} \mathrm{F}\left(11.1^{\circ} \mathrm{C}\right)\left[80.0^{\circ} \mathrm{F}\left(26.7^{\circ} \mathrm{C}\right)\right.$ at the bottom to $100.0^{\circ} \mathrm{F}\left(37.8^{\circ} \mathrm{C}\right)$ at the top of the drywell, which approximate an NMSF nominal operating-condition maximum] and $40.0^{\circ} \mathrm{F}\left(22.2^{\circ} \mathrm{C}\right)\left[80.0^{\circ} \mathrm{F}\left(26.7^{\circ} \mathrm{C}\right)\right.$ at the bottom to $120.0^{\circ} \mathrm{F}\left(48.9^{\circ} \mathrm{C}\right)$ at the top of the drywell, which approximate an NMSF worst-case maximum] were evaluated as well. In these cases, the containers progressively get hotter from the bottom to the top of the drywell, with the fourteenth container at the top being the hottest. A $20.0^{\circ} \mathrm{F}\left(11.1^{\circ} \mathrm{C}\right)$ bay-air TS gives container maximum temperatures of $121.8^{\circ} \mathrm{F}\left(49.9^{\circ} \mathrm{C}\right)$ at the bottom to $139.6^{\circ} \mathrm{F}\left(59.8^{\circ} \mathrm{C}\right)$ at the top of the drywell, whereas a $40.0^{\circ} \mathrm{F}\left(22.2^{\circ} \mathrm{C}\right)$ bay-air $\mathrm{TS}$ gives container maximum temperatures of $125.1^{\circ} \mathrm{F}\left(51.7^{\circ} \mathrm{C}\right)$ at the bottom to $154.1^{\circ} \mathrm{F}\left(67.8^{\circ} \mathrm{C}\right)$ at the top of the drywell. From these results, we can make the following statement:

for each degree (Fahrenheit or Celsius) of bay-air TS from the bottom to the top of the drywell, the container's maximum temperature increases by 0.728 of a degree.

Going from 0.0 to $20.0^{\circ} \mathrm{F}\left(0.0\right.$ to $\left.11.1^{\circ} \mathrm{C}\right)$ of $\mathrm{TS}$ increases the container's maximum temperature from $125.0^{\circ} \mathrm{F}\left(51.7^{\circ} \mathrm{C}\right)$ to $125.0^{\circ} \mathrm{F}+0.728 \cdot 20.0^{\circ} \mathrm{F}=139.6^{\circ} \mathrm{F}\left(51.7^{\circ} \mathrm{C}+0.728 \cdot\right.$ $\left.11.1^{\circ} \mathrm{C}=59.8^{\circ} \mathrm{C}\right)$. Going from 0.0 to $40.0^{\circ} \mathrm{F}\left(0.0\right.$ to $\left.22.2^{\circ} \mathrm{C}\right)$ of TS increases the container's maximum temperature from $125.0^{\circ} \mathrm{F}\left(51.7^{\circ} \mathrm{C}\right)$ to $125.0^{\circ} \mathrm{F}+0.728 \cdot 40.0^{\circ} \mathrm{F}=$ $154.1^{\circ} \mathrm{F}\left(51.7^{\circ} \mathrm{C}+0.728 \cdot 22.2^{\circ} \mathrm{C}=67.8^{\circ} \mathrm{C}\right)$. This linear dependence provides a good rule of thumb that can be used to include the effect of bay TS on the container's maximum temperature from a constant bay temperature boundary condition.

The axial heat-flux profile from the outer surface of the drywell pipe to the bay air was evaluated to be peaked at the top of the drywell for no bay TS, at the middle of the drywell for $20.0^{\circ} \mathrm{F}\left(11.1^{\circ} \mathrm{C}\right)$ bay TS, and at the bottom of the drywell for $40.0^{\circ} \mathrm{F}$ $\left(22.2^{\circ} \mathrm{C}\right)$ bay TS. The effect of TS is to reduce the air temperature difference across the drywell at higher axial locations. This reduces convective heat transfer at the higher drywell inner and outer surfaces. As a result, more heat is transferred by convective air flow down the drywell inner surface and by conduction heat transfer axially in the drywell. More heat is transferred from the top to the bottom of the drywell pipe 
where it is lost by inner- and outer-surface convection heat transfer to the cooler bay air at the bottom of the drywell.

The effect of TS on the axial heat-flux profile from the outer surface of the drywell pipe is important because it couples the CFX model for the drywell pipe to the CFX model for the NMSF. The NMSF model ${ }^{10}$ requires the drywell axial heat-flux profiles to evaluate (1) bay-air flow past the drywell pipes and through the facility and (2) vertical TS of the bay air. The drywell model requires the bay air velocity to evaluate its forced-convection, outer-surface HTC and the bay-air axial temperature profile to define its temperature boundary condition. The results of both models need to be consistent for an accurate simulation. This will need to be done for the final design by adjusting the input-data specification for each model by an iterative process until the results of both models are consistent. For the current analysis, the drywell heat-flux profile was assumed to be uniform axially in the NMSF model. ${ }^{10}$ Its bay flow velocity but not its vertical TS of the bay air was used in the drywell model.

The TSAP model of the drywell is simpler and more flexible than the CFX model, but it requires approximating assumptions for the effects of air flow and TS that the CFX model does not have to make. The convenience of using TSAP can be justified only if the error from its approximations is sufficiently small. With the results from the CFX model of the drywell, we have benchmarked the accuracy of TSAP by evaluating an "equivalent" TSAP model. All previous TSAP models of the drywell ${ }^{3-5}$ differ in several modeling parameters so that an equivalent model had to be developed for this analysis. The TSAP results from that model are in reasonable agreement with the CFX model results. For an $80.0^{\circ} \mathrm{F}\left(26.7^{\circ} \mathrm{C}\right)$ bay-air temperature boundary condition, the container's maximum temperature was evaluated by TSAP to be $129.4^{\circ} \mathrm{F}\left(54.1^{\circ} \mathrm{C}\right)$. This compares with $125.0^{\circ} \mathrm{F}\left(51.67^{\circ} \mathrm{C}\right)$ from the CFX model for the hottest container. Four areas of modeling approximation in the TSAP model were adjusted to correct for observed local temperature differences (based on an understanding of their cause). The adjusted TSAP model determined a container maximum temperature of $125.1^{\circ} \mathrm{F}\left(51.72^{\circ} \mathrm{C}\right)$, which is in agreement with the CFX model.

A further modification was made to the TSAP model to model a plutonium-helium mixture as a uniform mixture in $100 \%$ of the volume of the mixture container, the helium gap between the mixture and boundary containers, and the uniform generation of the $15-\mathrm{W}$ heat source in the plutonium-helium mixture volume. This provides a more realistic container model that the CFX model approximated with a solid stainless-steel container and the 15-W heat source in both the container and support plate. This realistic-container TSAP model determined a maximum plutonium-helium mixture temperature of $144.6^{\circ} \mathrm{F}\left(62.5^{\circ} \mathrm{C}\right)$. The plutoniumhelium mixture's thermal conductivity was approximated by volume-fraction weighting the thermal conductivities of plutonium and helium (with temperature dependence). ${ }^{3}$ For small pieces of plutonium, a higher weighting of the helium thermal conductivity is needed to account for the limited surface contact between the plutonium pieces. Increasing the weighting of helium thermal conductivity 
will decrease the thermal conductivity of the plutonium-helium mixture and increase the plutonium-helium mixture temperature.

\section{ACKNOWLEDGMENTS}

The author wishes to thank George Niederauer, F. Jeffrey Martin, and Thad Knight for reviewing this report and Gloria Mirabal and Lisa Rothrock for their editorial work.

\section{REFERENCES}

1. "NMSF Renovation Temperature Limits," Los Alamos National Laboratory memorandum from T. D. Knight to L. M. Martinez, TSA-8:95-54 (March 20, 1995).

2. R. G. Steinke, "One-Dimensional Heat-Transfer Analysis of the Drywell Pipe in the Nuclear Material Storage Facility," Los Alamos National Laboratory internal report TSA8-LA-9 (December 12, 1994).

3. R. G. Steinke, "Heat-Transfer Modeling of the Drywell Pipe in the Nuclear Material Storage Facility," Los Alamos National Laboratory internal report TSA8-LA-10 (December 12, 1994).

4. R. G. Steinke, "Two-Dimensional Heat-Transfer Analysis of the Drywell Pipe in the Nuclear Material Storage Facility," Los Alamos National Laboratory internal report TSA8-LA-11 (January 31, 1995).

5. R. G. Steinke, "Two-Dimensional Heat-Transfer Analysis of the Drywell Pipe in the Nuclear Material Storage Facility-Supplement: Revised Model with a Storage Cage Rather Than a Storage Pipe," Los Alamos National Laboratory internal report TSA8-LA-12 (March 3, 1995).

6. R. G. Steinke, "Heat-Transfer Analysis of the Containment Vessel from an AT400A Container in the Drywell Pipe for the Nuclear Material Storage Facility," Los Alamos National Laboratory internal report TSA8-LA-13 (March 6, 1995).

7. R. G. Steinke, "Two-Dimensional Heat-Transfer Transient Response of the Drywell-Pipe Components in the Nuclear Material Storage Facility," Los Alamos National Laboratory internal report TSA8-LA-14 (March 7, 1995).

8. T. Kao, computer code TSAP (independent engineer, New Jersey, 1982), Version 1.0.1, modified by R. G. Steinke (December 1993).

9. W. R. Bohl, "Transient Heatup of the NMSF," Los Alamos National Laboratory internal report TSA8-LA-15 (March 17, 1995).

10. W. S. Gregory, "NMSF Heat Removal Analysis," Los Alamos National Laboratory internal report TSA8-LA-20 (March 1995). 
11. CFX 4.1 Flow Solver User Guide (Computational Fluid Dynamics Services, Harwell Laboratory, Oxfordshire, UK, October 1995).

12. "Request for Additional Analyses with Axially Varying Bay-Air Temperature Boundary Conditions," facsimile from Jim. Corll to Kin Lam and Thad Knight (August 6, 1996).

13. Kin L. Lam, "Nuclear Material Storage Facility Drywell Thermal Analysis," Los Alamos National Laboratory report LA-UR-96-3314 (October 1996).

14. W. H. McAdams, Heat Transmission (McGraw-Hill Book Company, Inc., New York, pp. 272-274, 1954). 


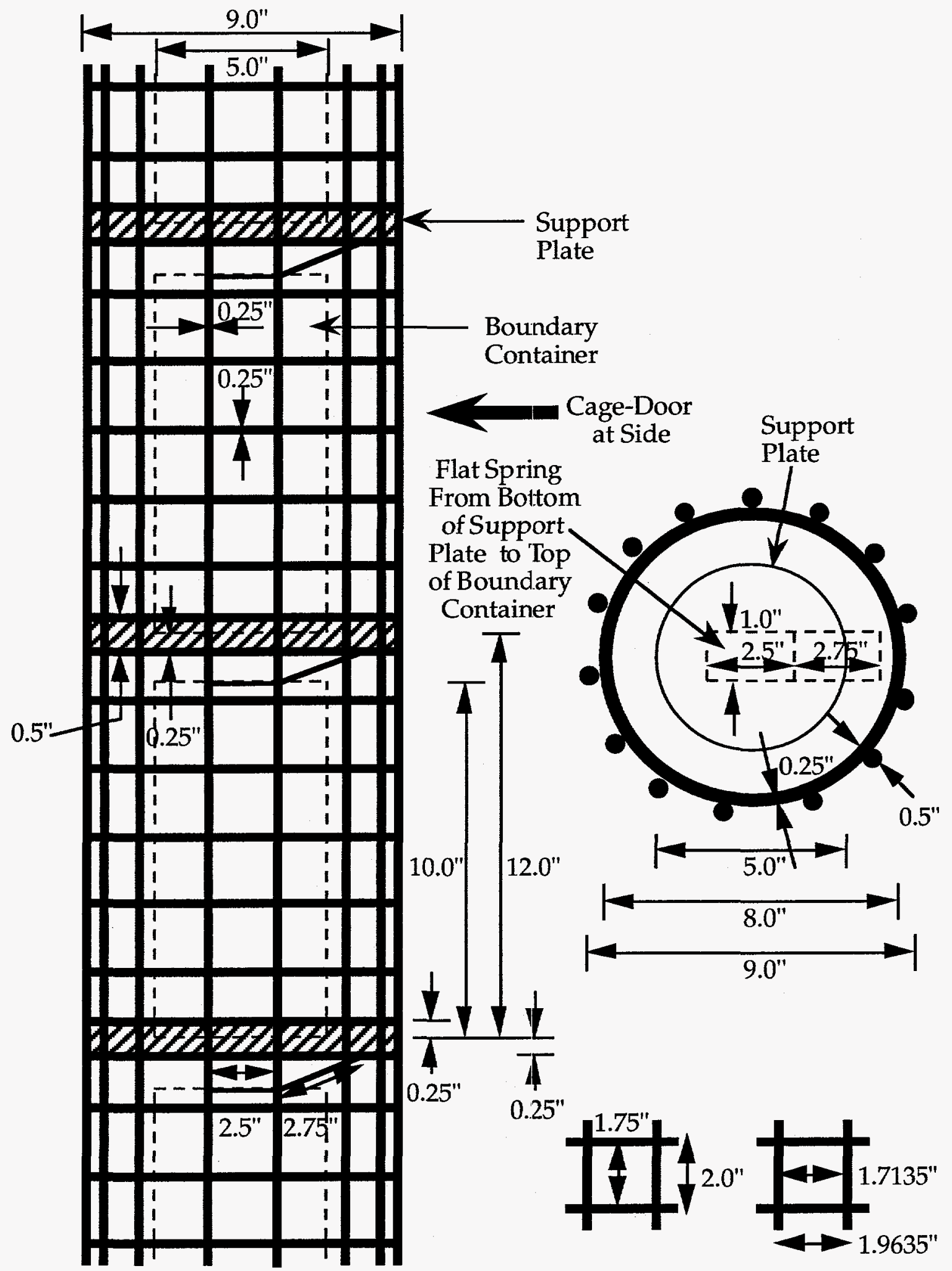

Fig. 1. Diagram of an assumed storage cage for boundary containers that are to be positioned within the NMSF drywell pipe. 


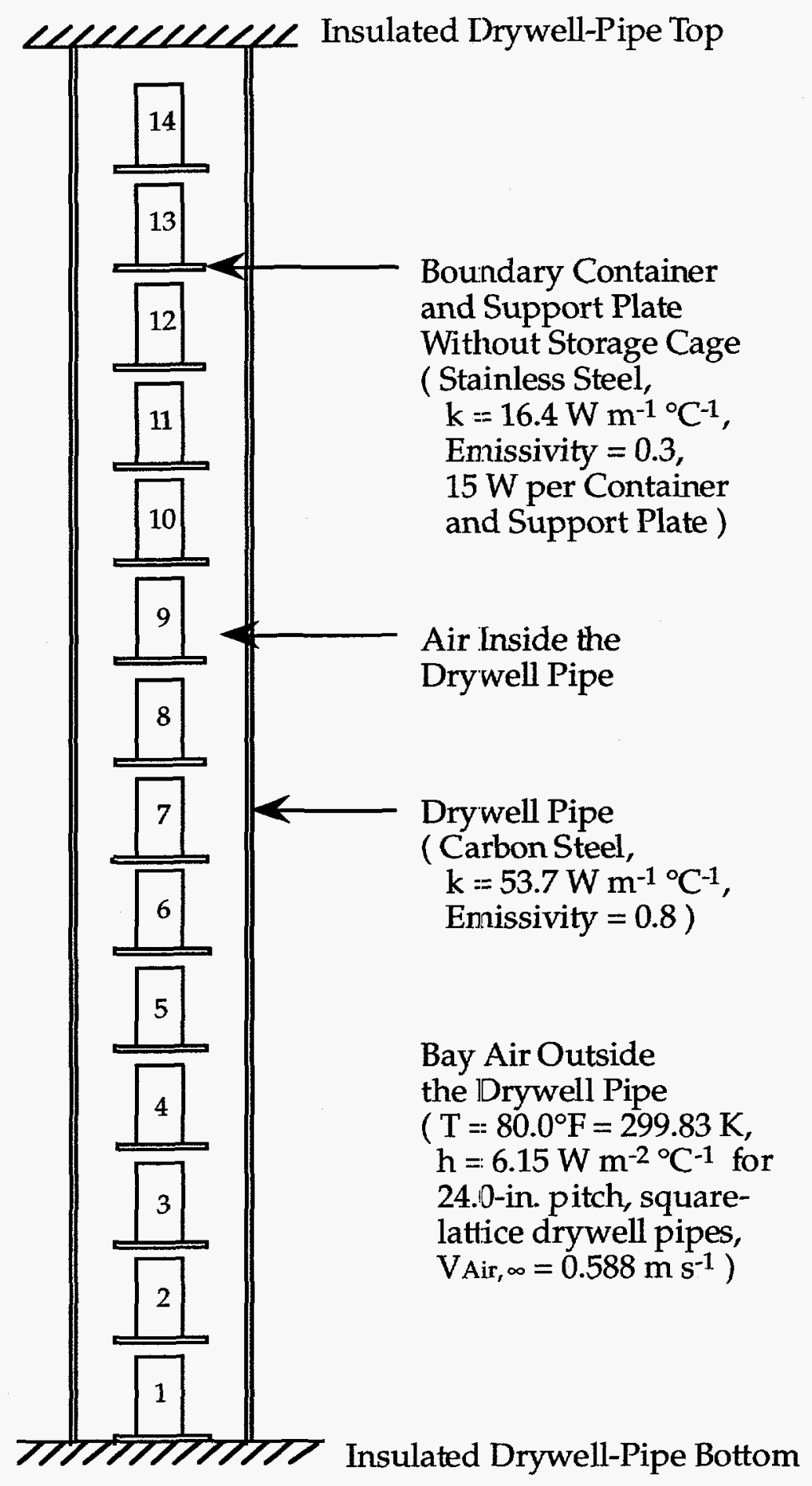

Fig. 2. Diagram of the NMSF drywell-pipe, CFX heat-transfer model. The storagecage structure holding the support plates is not modeled. 


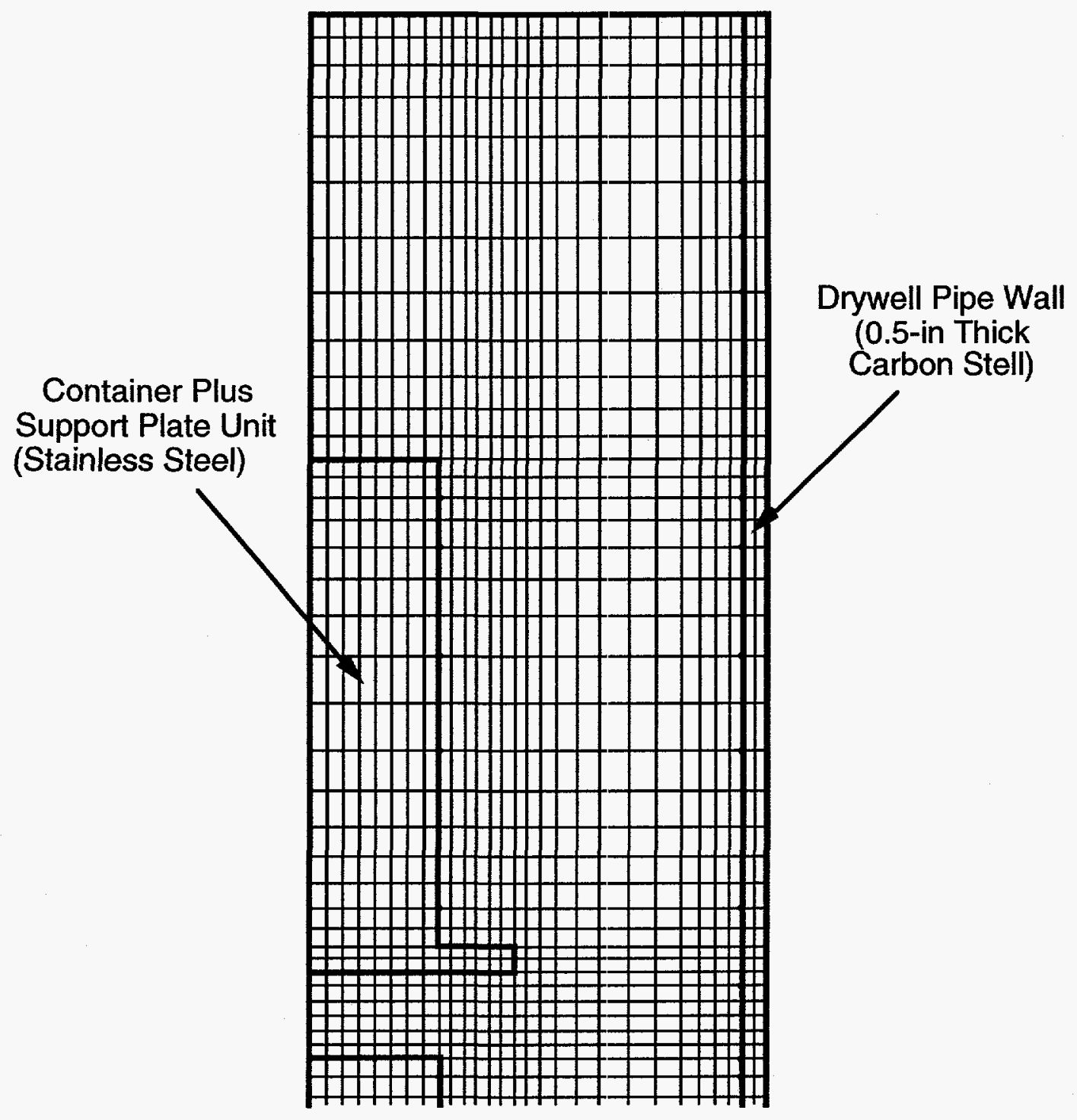

Fig. 3. Part of the axisymmetric computational mesh that shows the top boundarycontainer and support-plate unit and the drywell-pipe wall. The radial coordinates of the boundary-container outer wall, support-plate edge, and drywell-pipe inner surface are $2.5 \mathrm{in.,} 4.0 \mathrm{in.}$, and 8.5 in., respectively. 

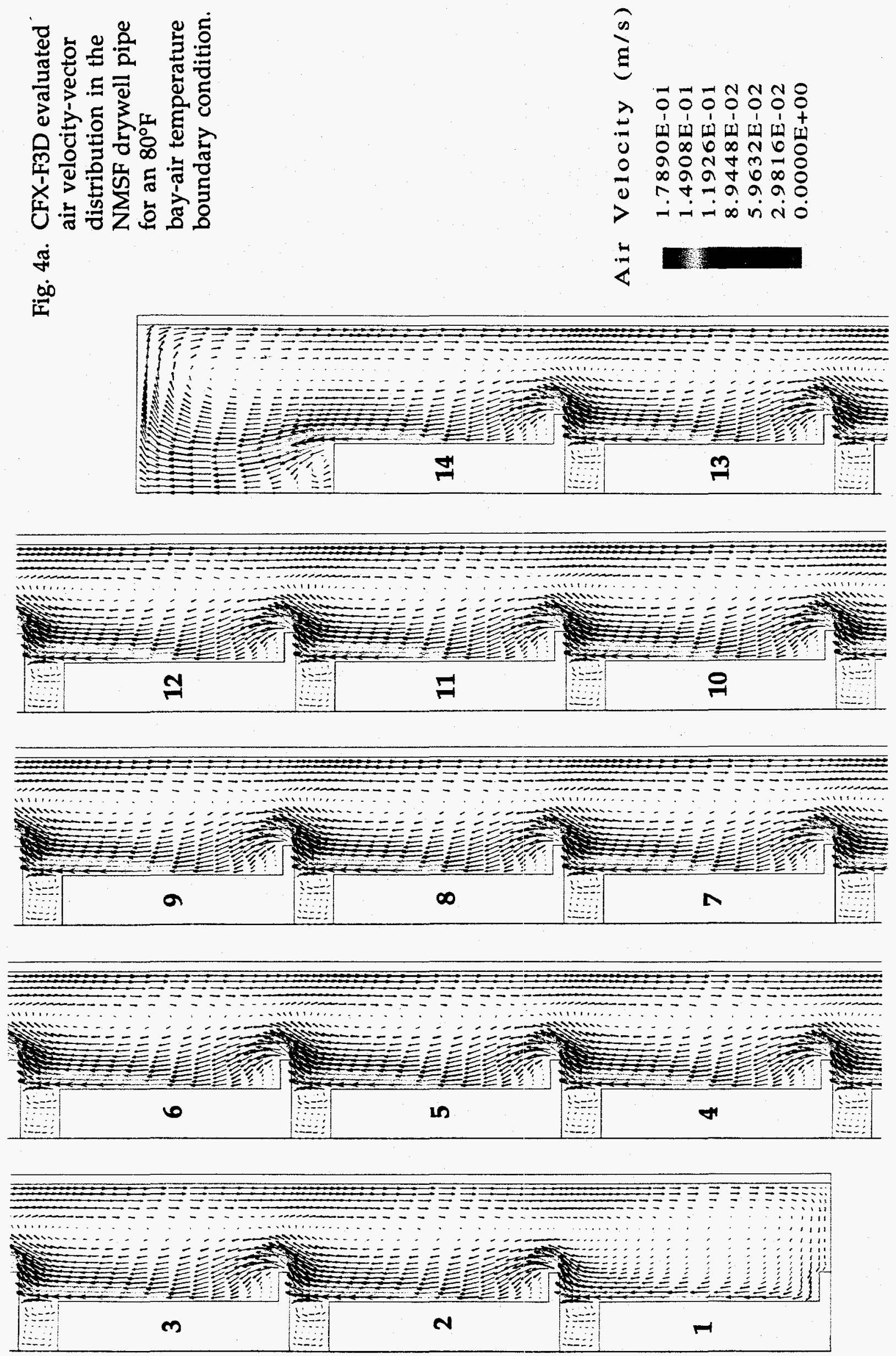

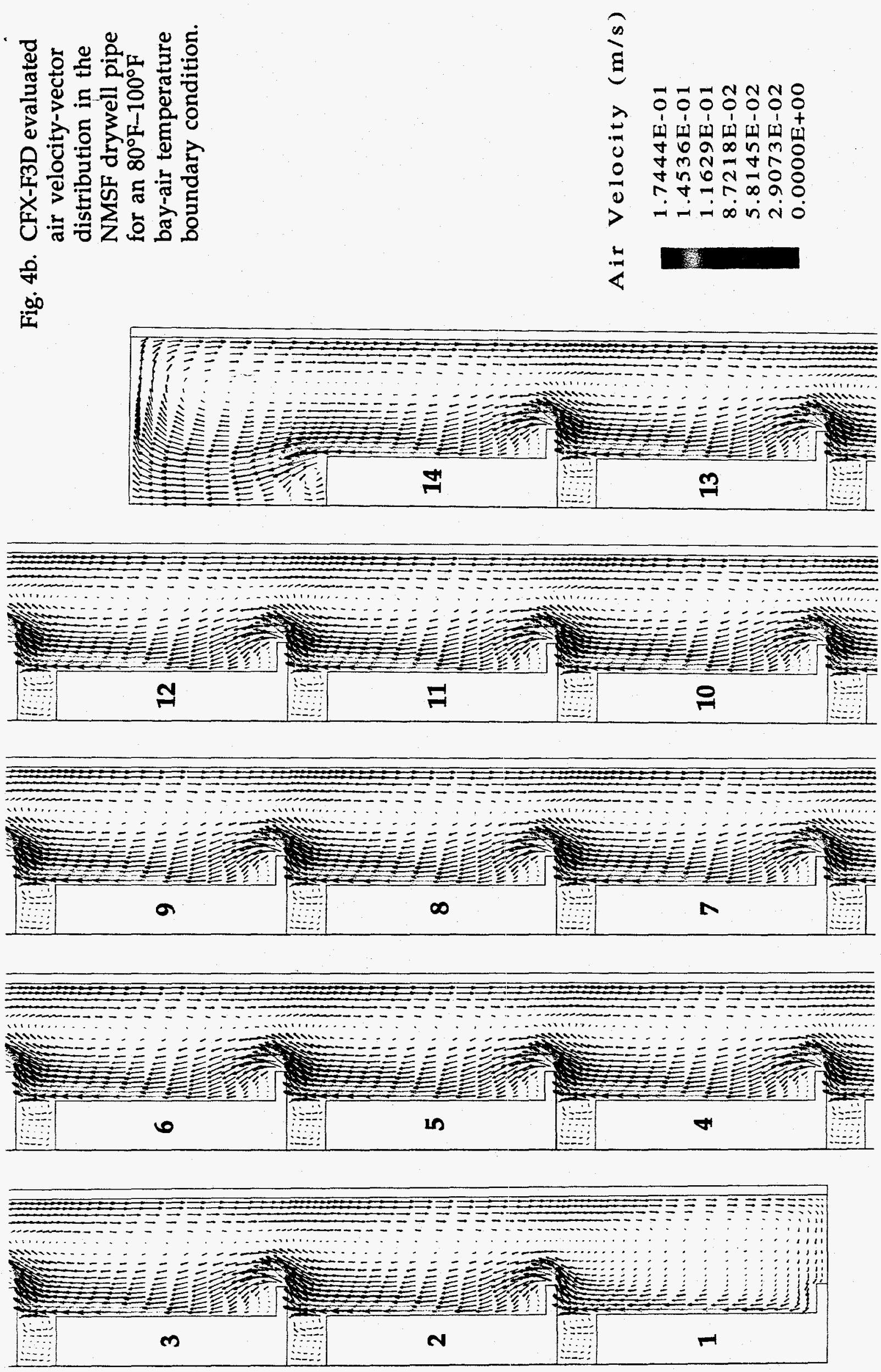

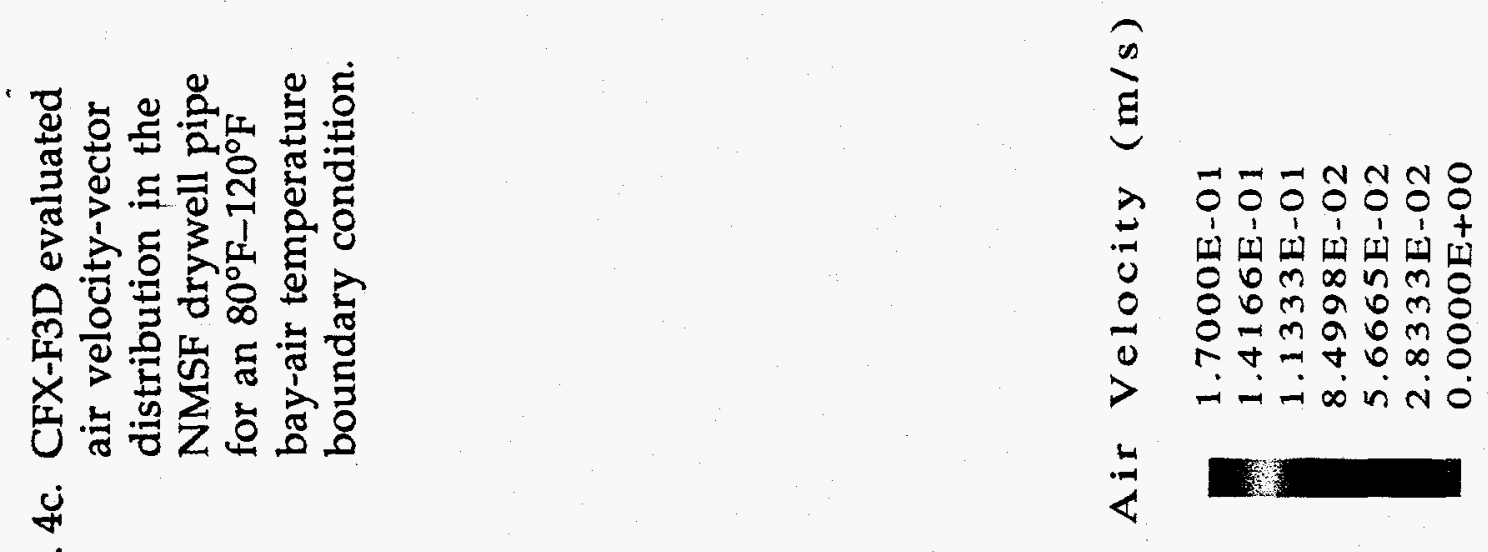

$\dot{00}$
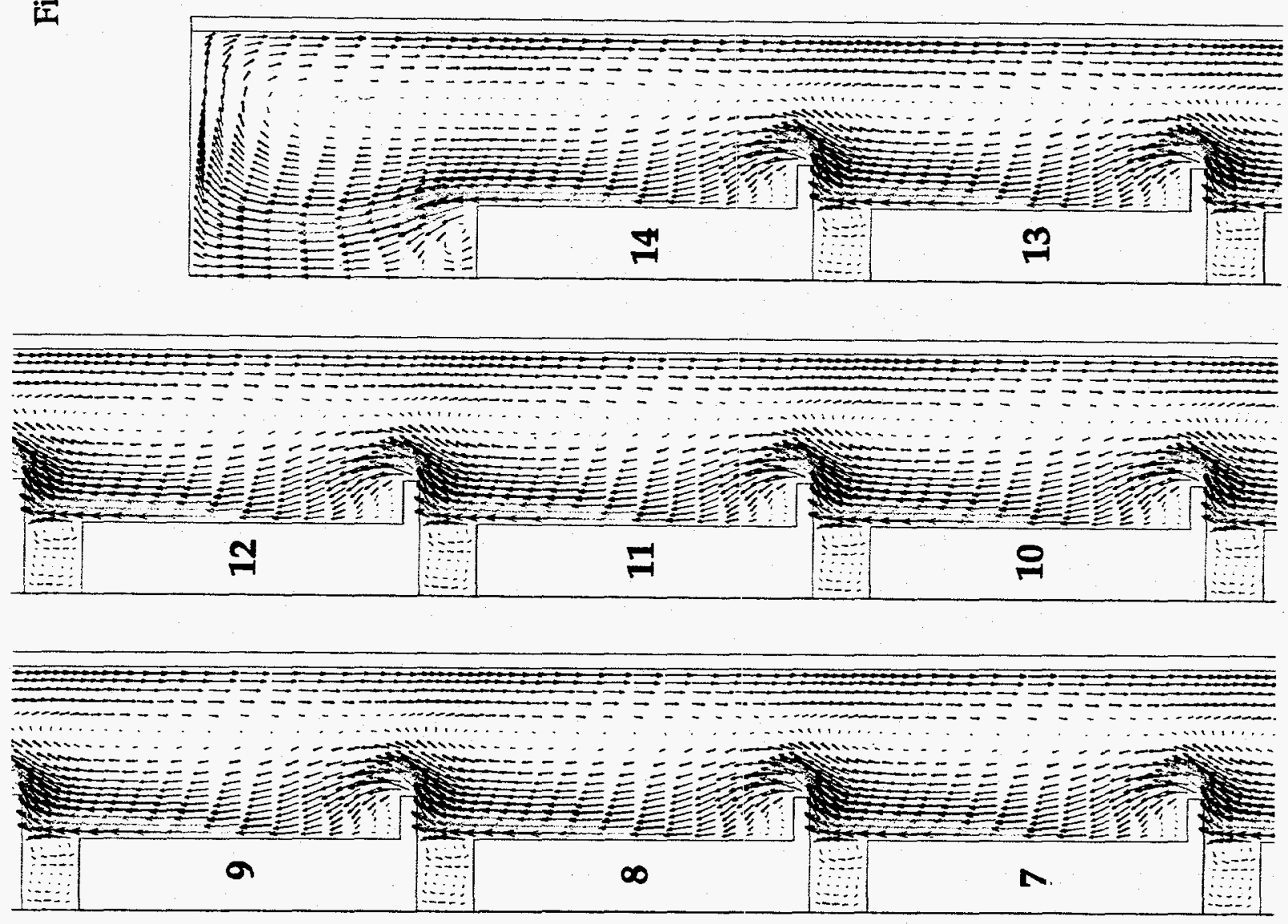

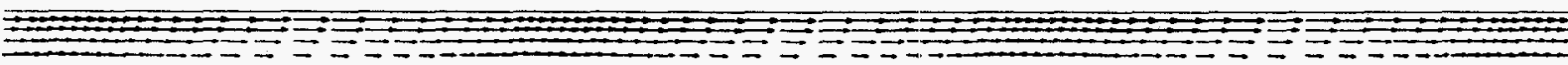
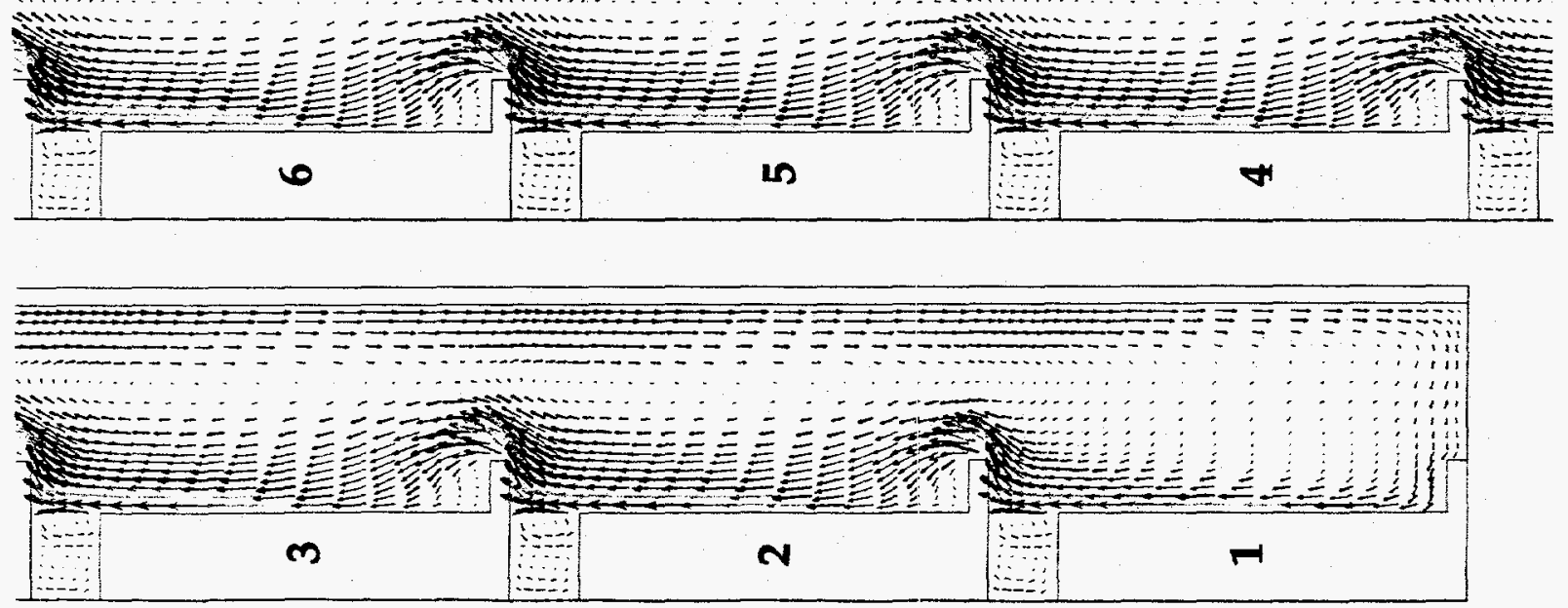

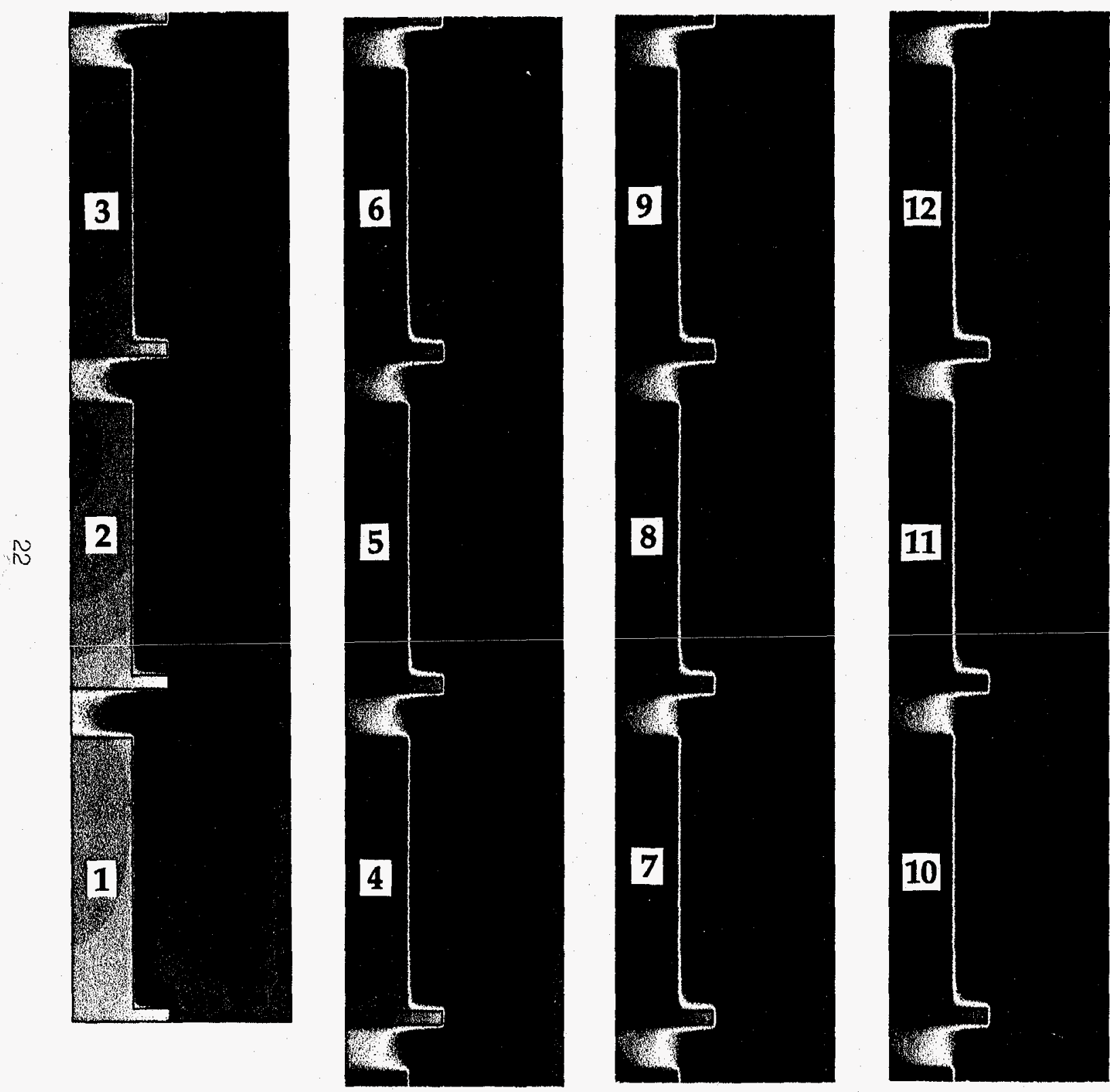

Fig. 5a. CFX-F3D evaluated temperature

distribution in the NMSF drywell pipe for an $80^{\circ} \mathrm{F}$

bay-air temperature boundary condition.

Temperature (K)

$3.2482 \mathrm{E}+02$

$3.2126 \mathrm{E}+02$

$1769 \mathrm{E}+02$

$3.1413 \mathrm{E}+02$

$3.1056 \mathrm{E}+02$

$3.0699 \mathrm{E}+02$

$3.0343 E+02$ 

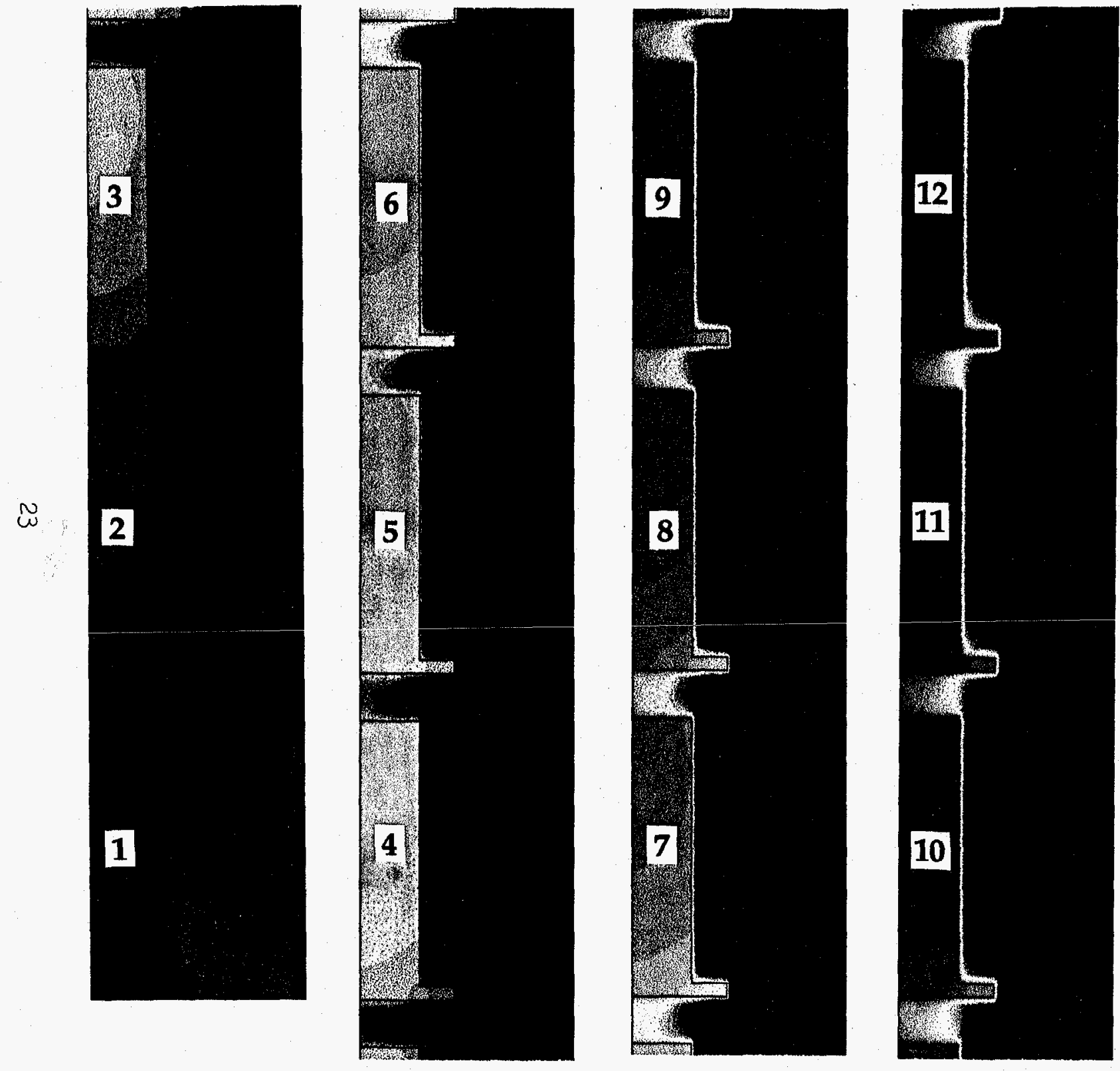

Fig. 5b. CFX-F3D evaluated temperature

distribution in the NMSF drywell pipe for an $80^{\circ} \mathrm{F}-100^{\circ} \mathrm{F}$ bay-air temperature boundary condition.

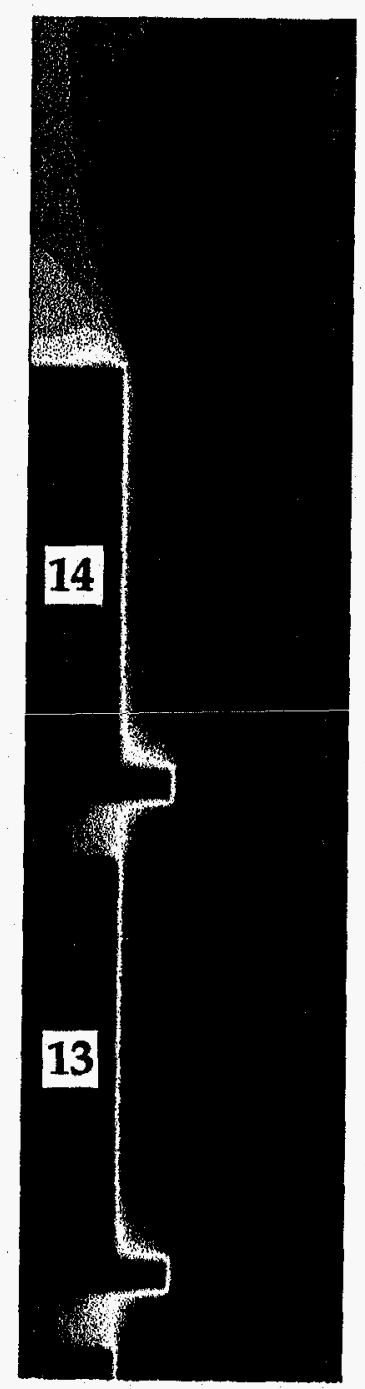

Temperature (K)

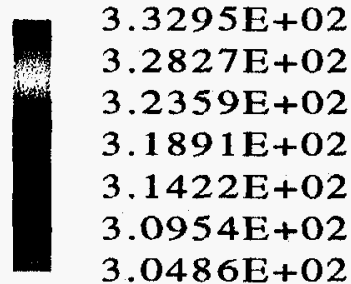



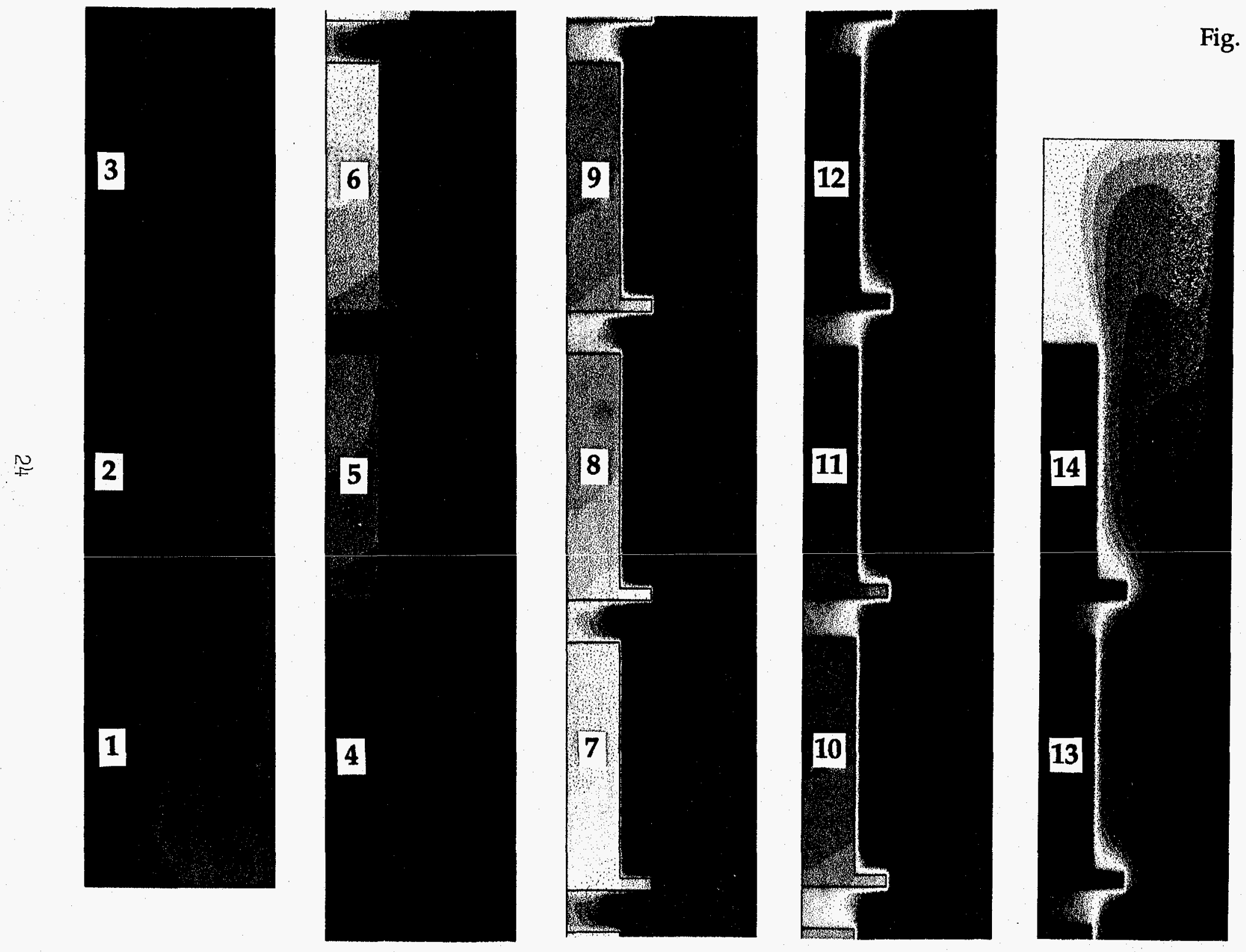

Fig. 5c. CFX-F3D evaluated temperature distribution in the NMSF drywell pipe for an $80^{\circ} \mathrm{F}-120^{\circ} \mathrm{F}$ bay-air temperature boundary condition.

Temperature (K)

$3.4097 \mathrm{E}+02$

1.3523E+02

$3.2949 \mathrm{E}+02$

$3.2375 \mathrm{E}+02$

3.1801 E+O2

$3.1227 \mathrm{E}+02$

$3.0653 \mathrm{E}+02$ 

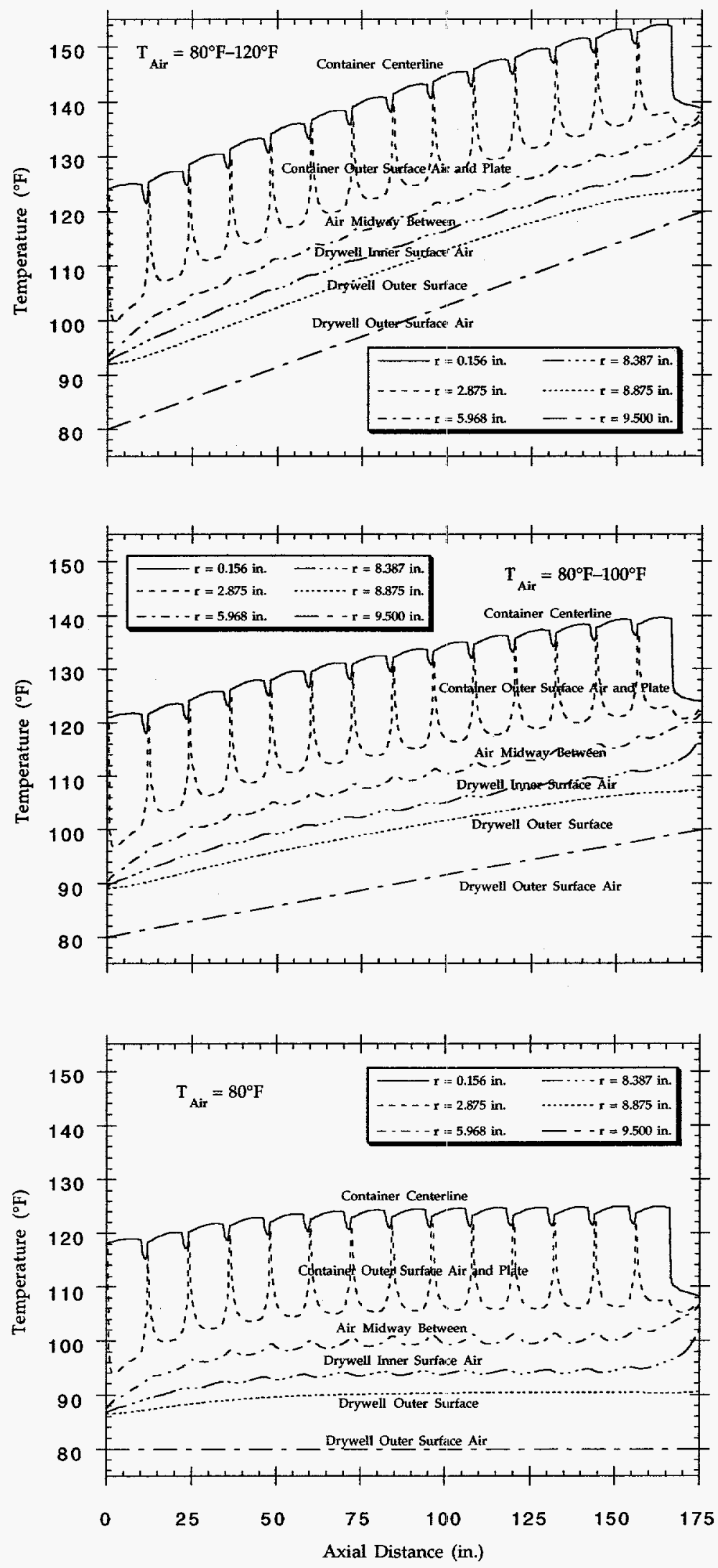

Fig. 6. Axial temperature profiles in the NMSF drywell. 

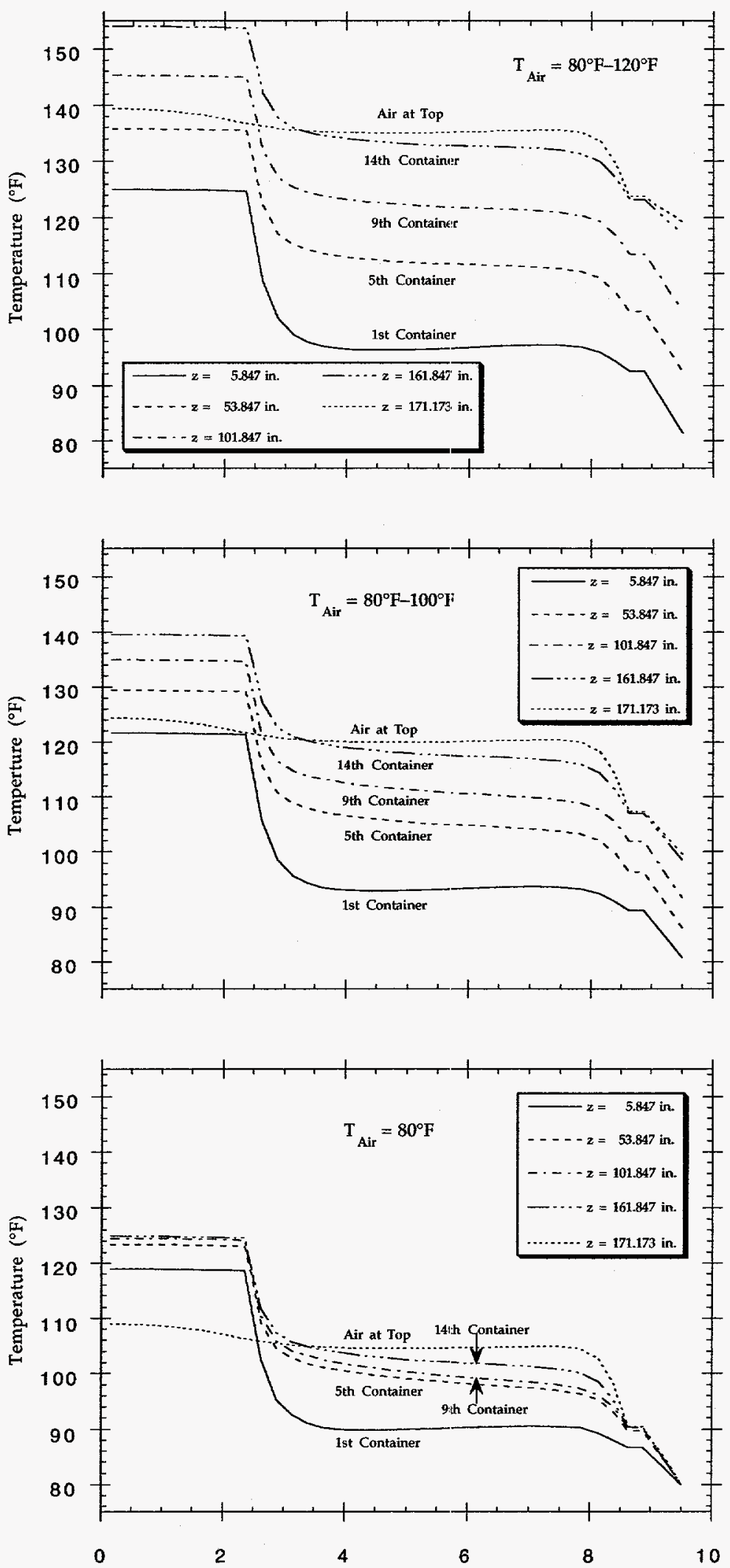

Fig. 7. Radial temperature profiles in the NMSF drywell. 

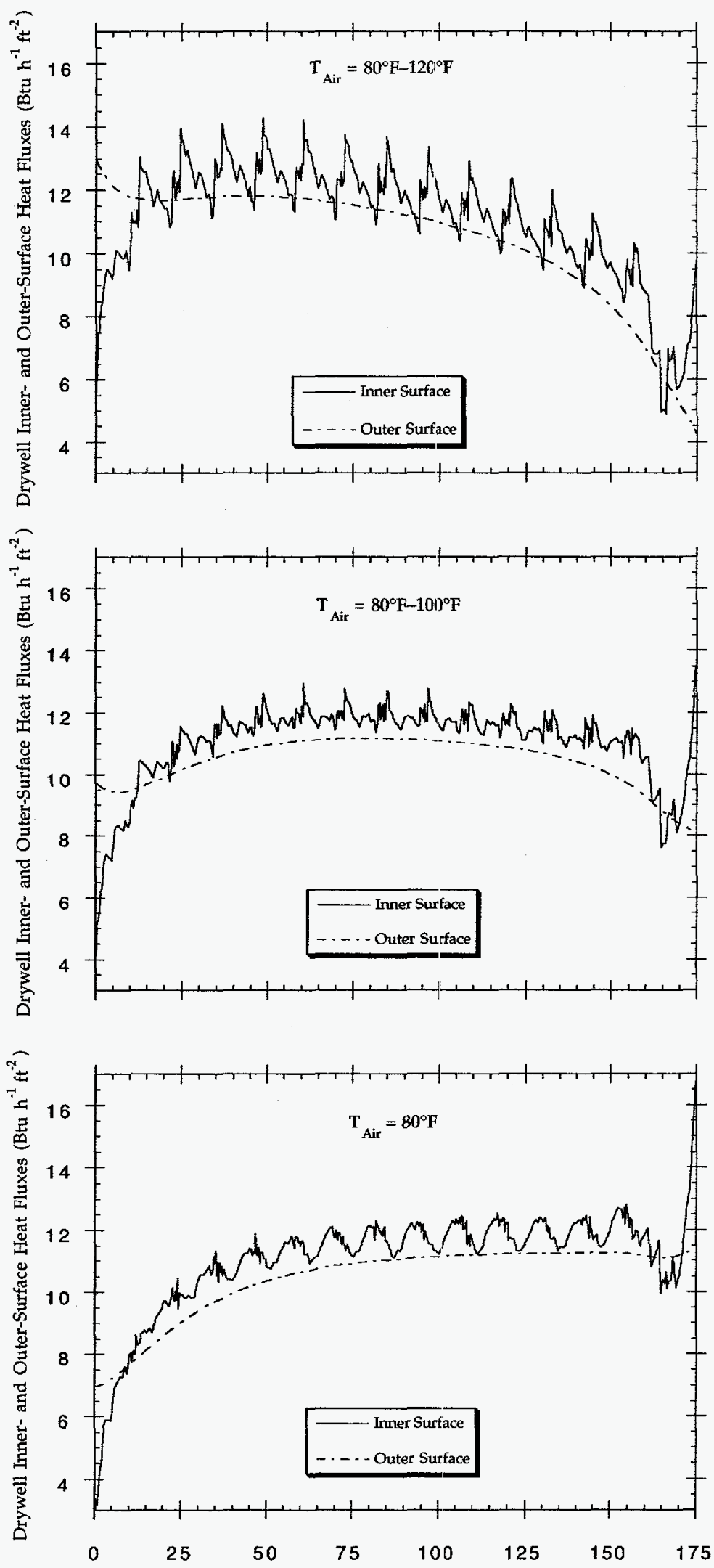

Fig. 8. Axial heat-flux profiles at the NMSF drywell inner and outer surfaces. 


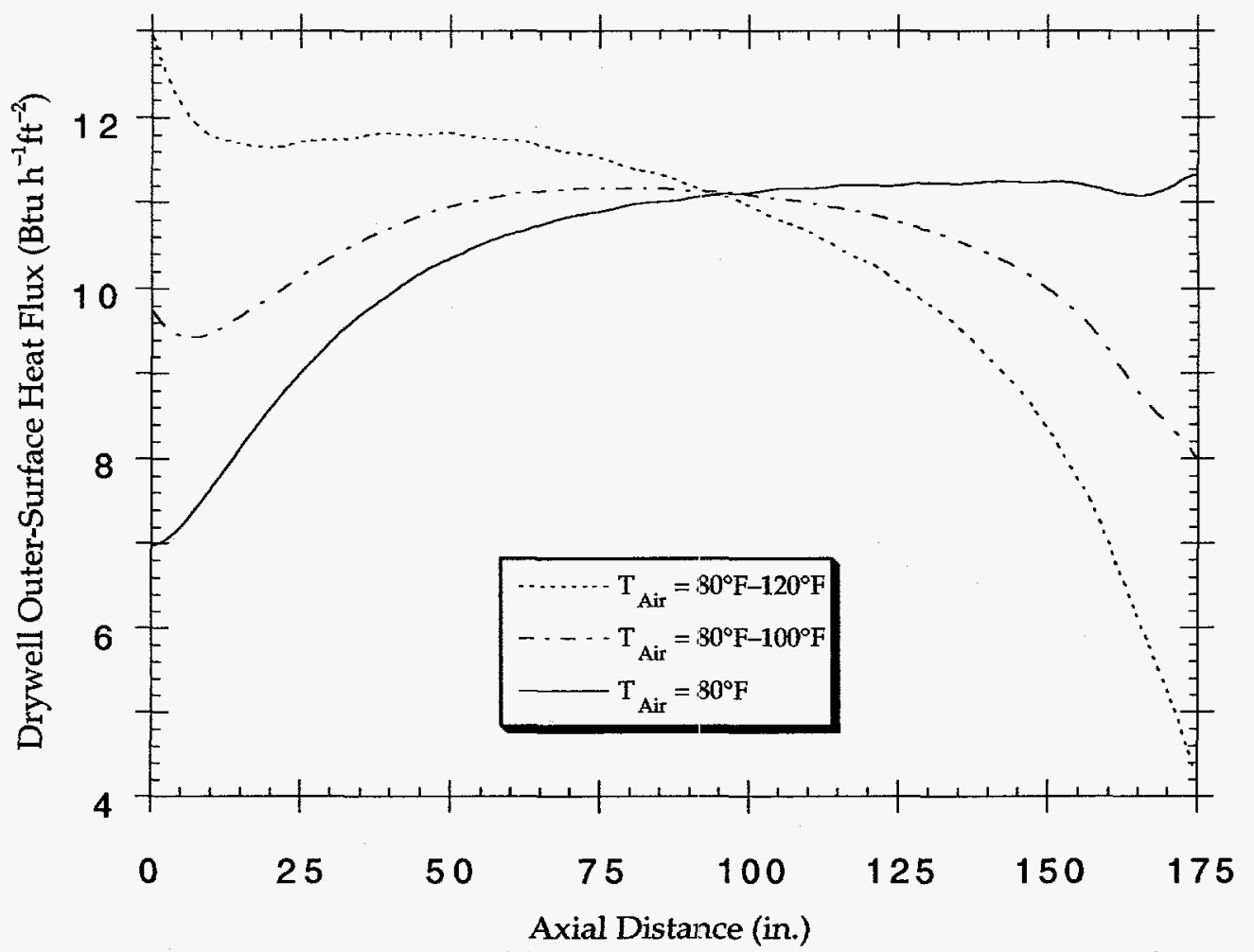

Fig. 9. Axial heat-flux profiles at the NMSF drywell outer surface.

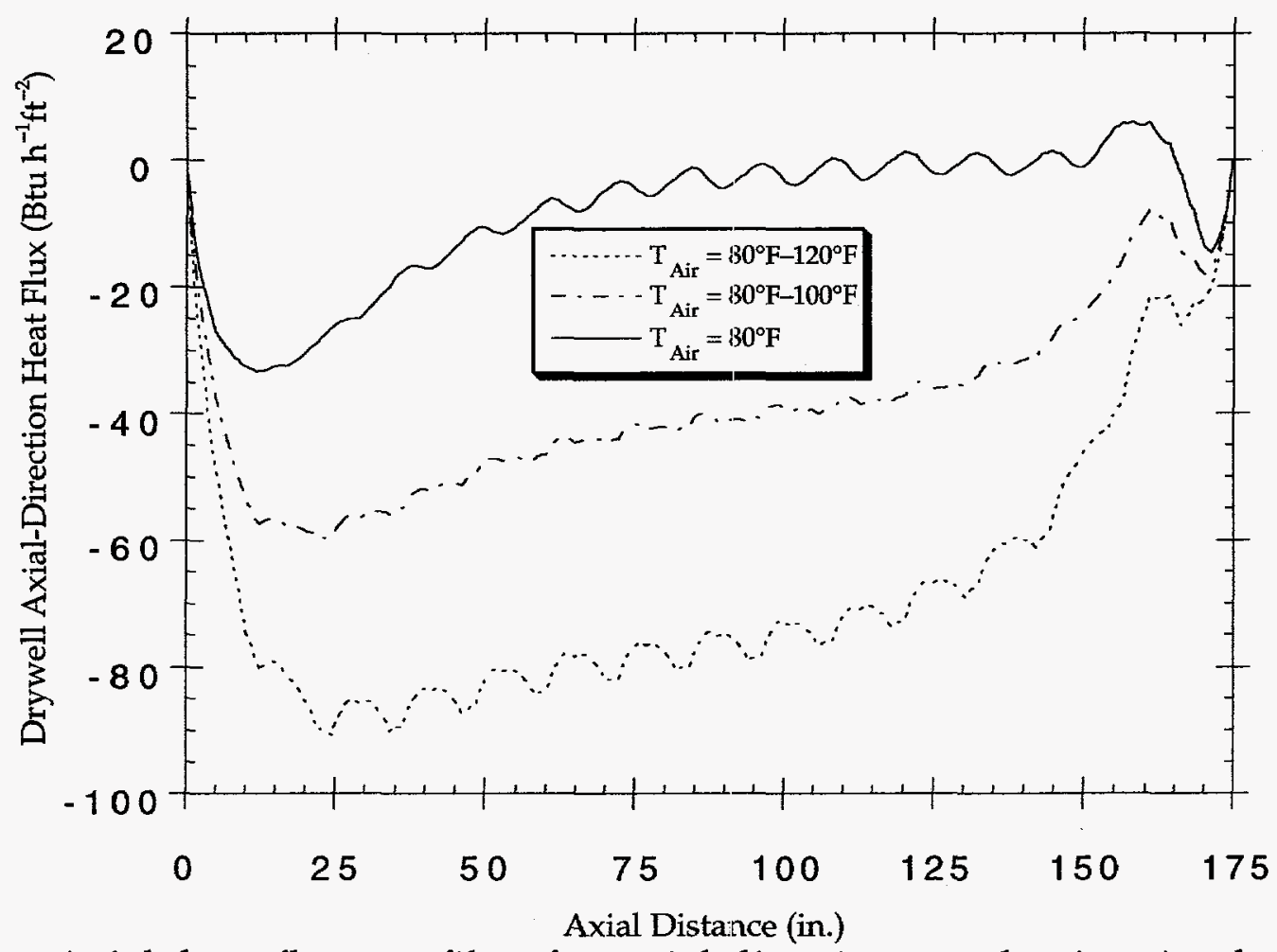

Fig. 10. Axial heat-flux profiles for axial-direction conduction in the NMSF drywell pipe. 


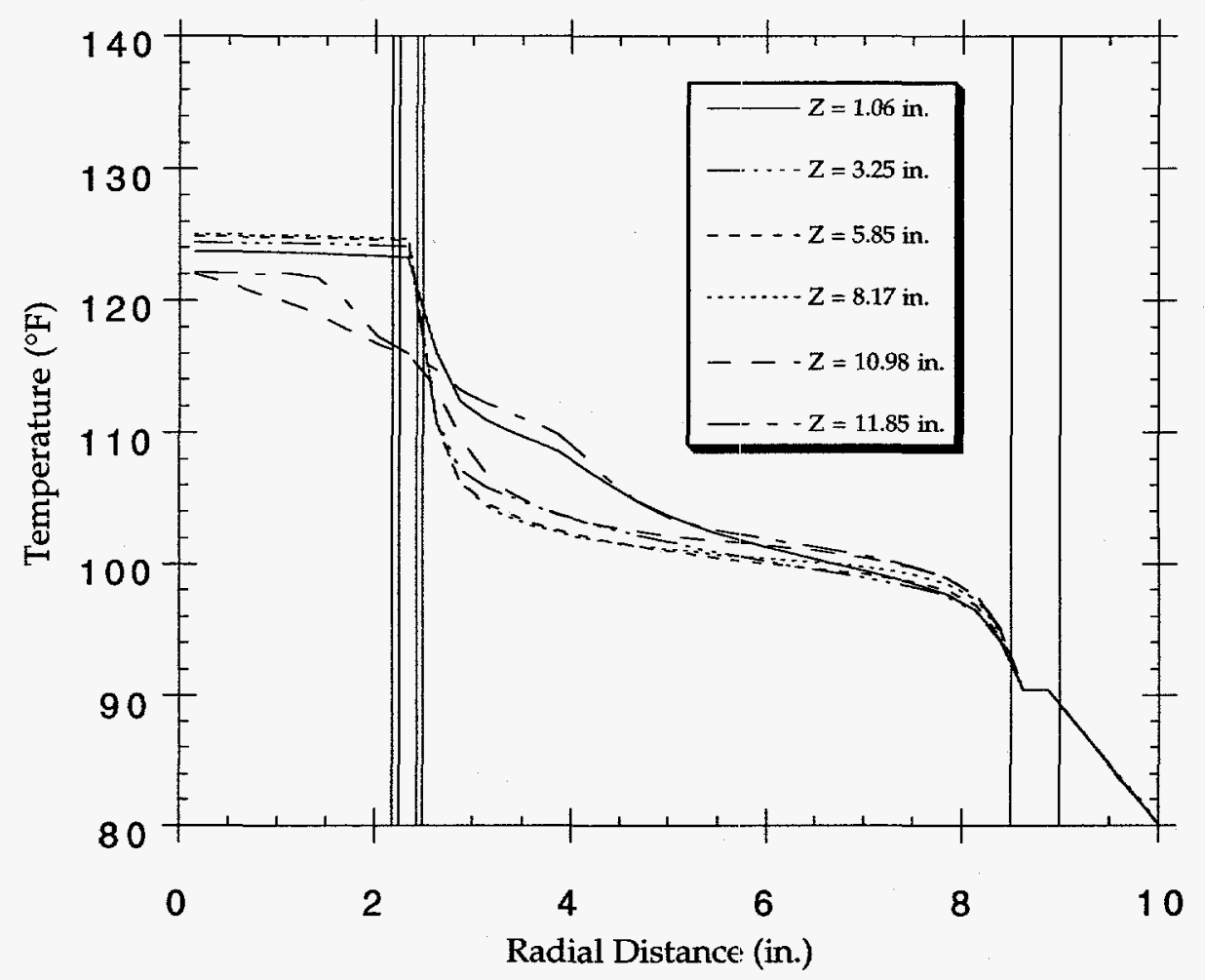

Fig. 11. Radial temperature profiles in the hottest container (13th from the bottom) of the CFX drywell model for $\mathrm{T}(\mathrm{z})_{\mathrm{Air}, \mathrm{BC}}=80^{\circ} \mathrm{F}$.

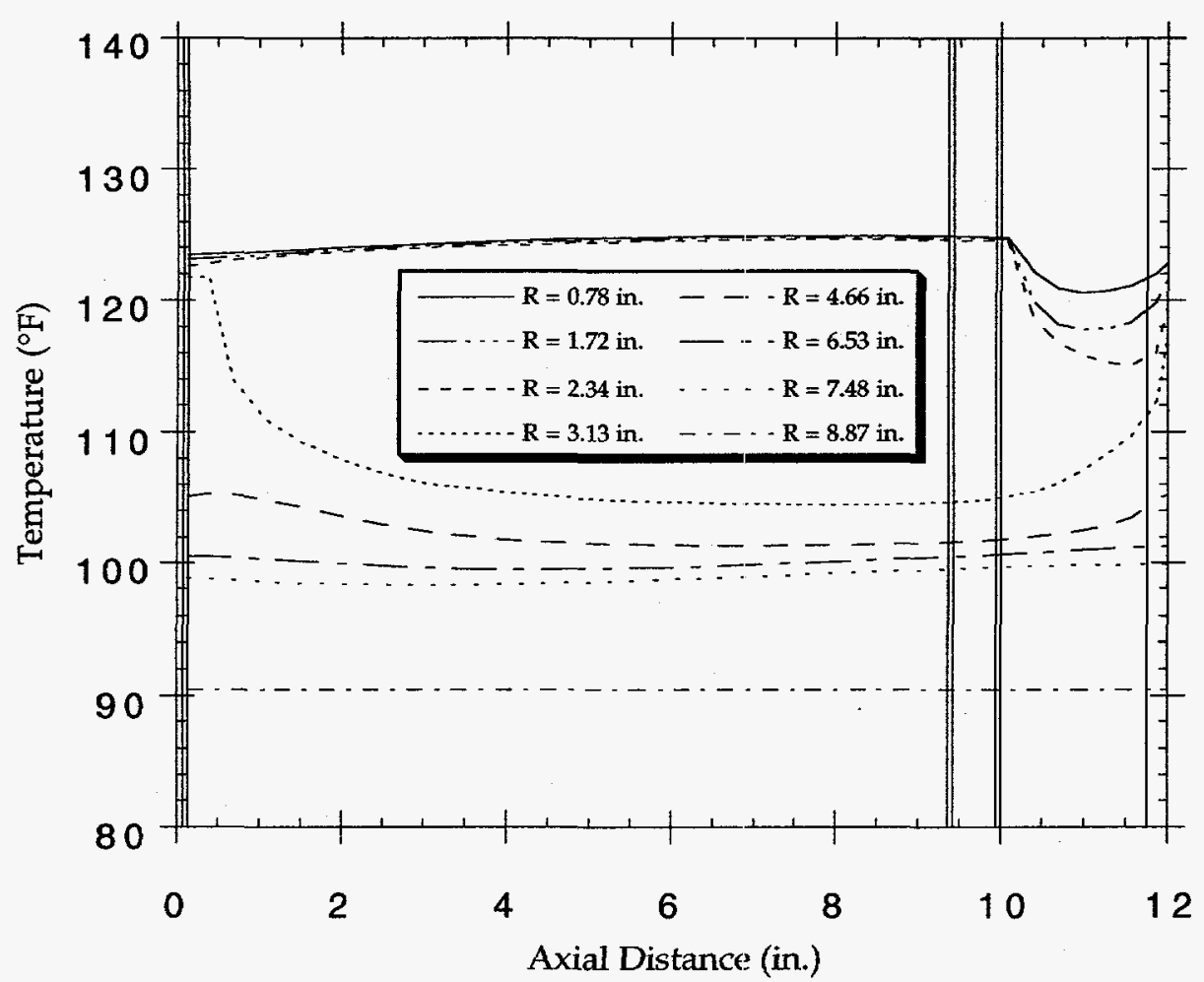

Fig. 12. Axial temperature profiles in the hottest container (thirteenth from the bottom) of the CFX drywell model for $\mathrm{T}(\mathrm{z})_{\mathrm{Air}, \mathrm{BC}}=80^{\circ} \mathrm{F}$. 


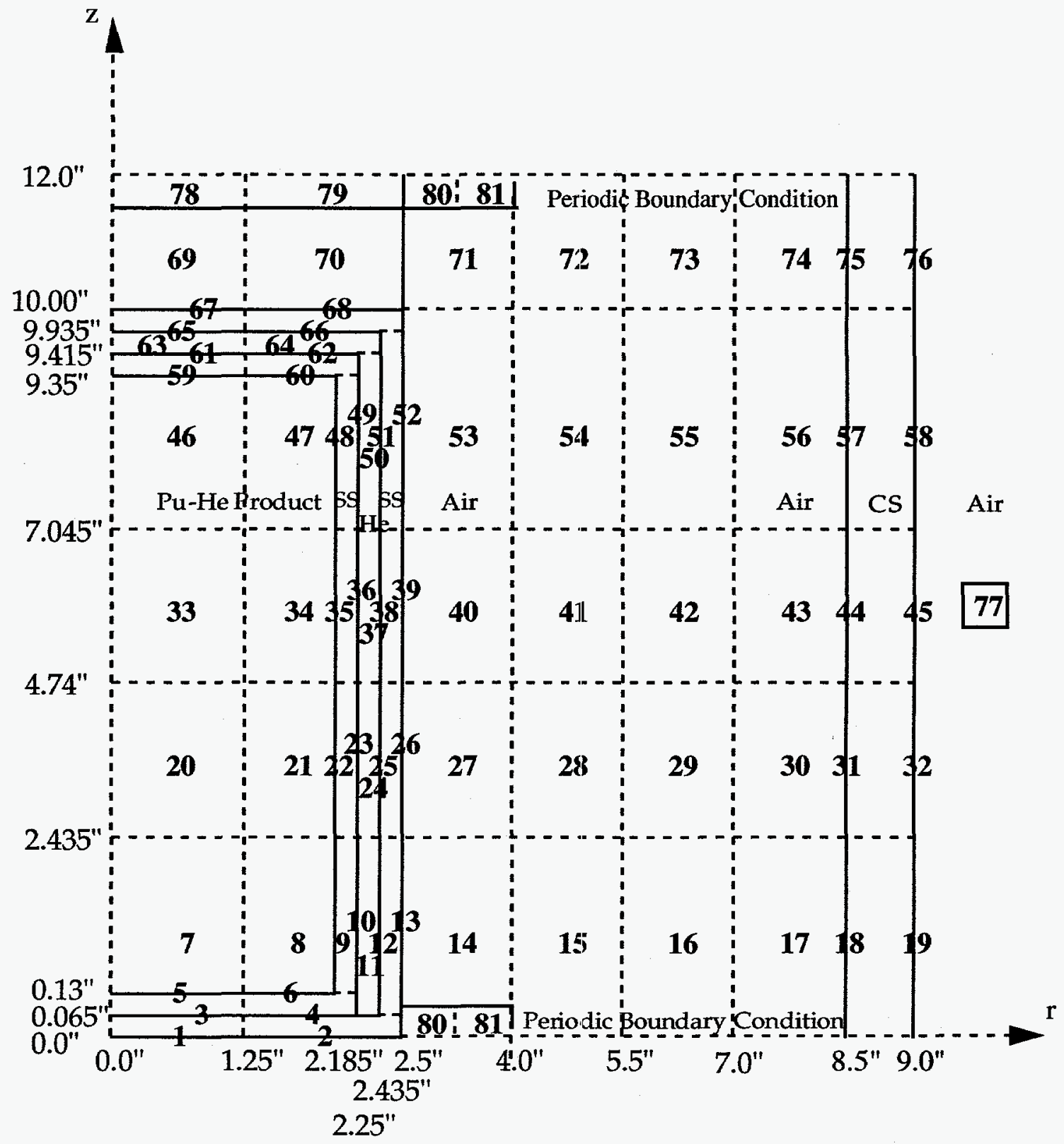

Fig. 13. TSAP model of the CFX drywell model for a single container. 


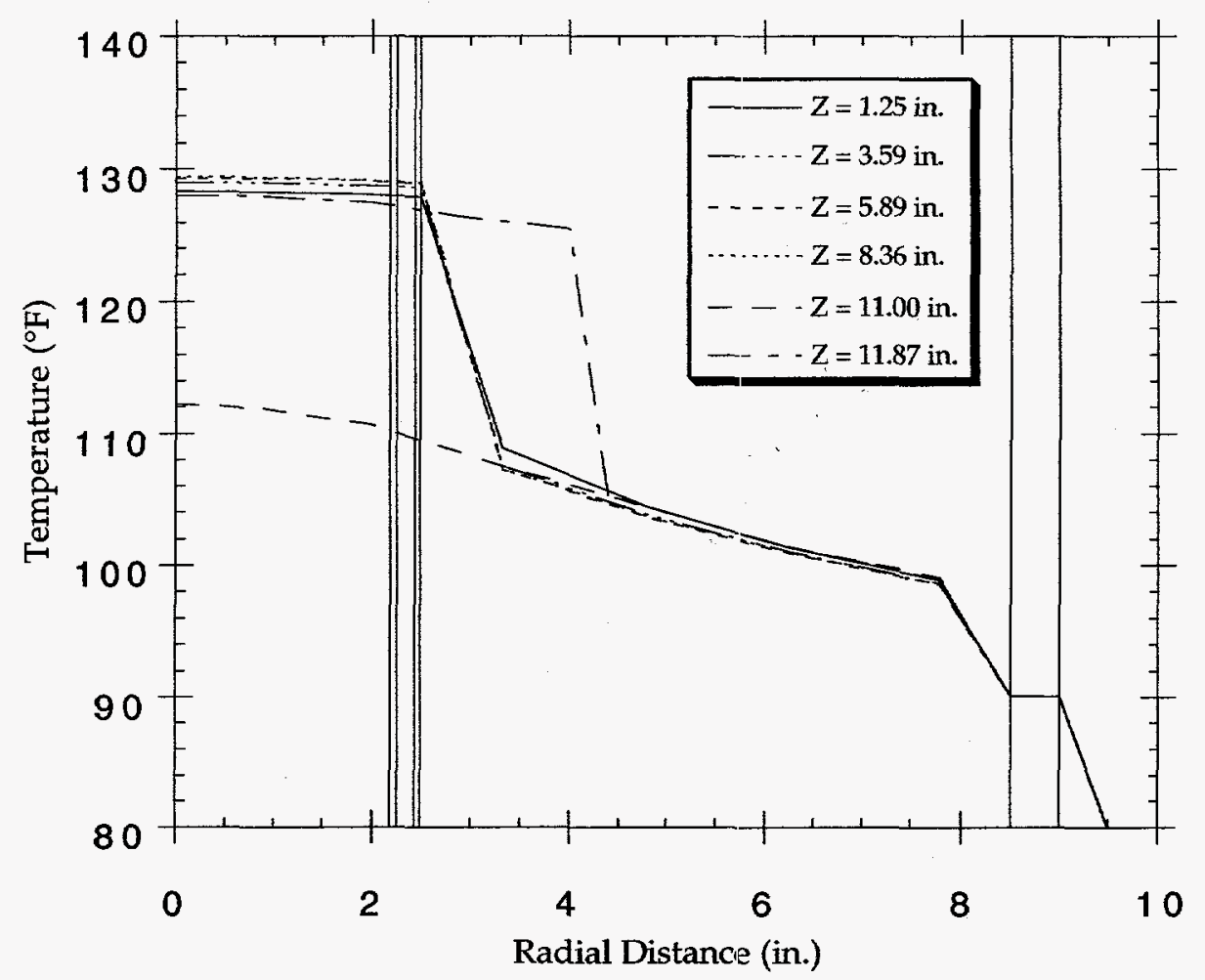

Fig. 14. Radial temperature profiles evaluated by TSAP for the CFX drywell model with $\mathrm{T}(\mathrm{z})_{\mathrm{Air}, \mathrm{BC}}=80^{\circ} \mathrm{F}$.

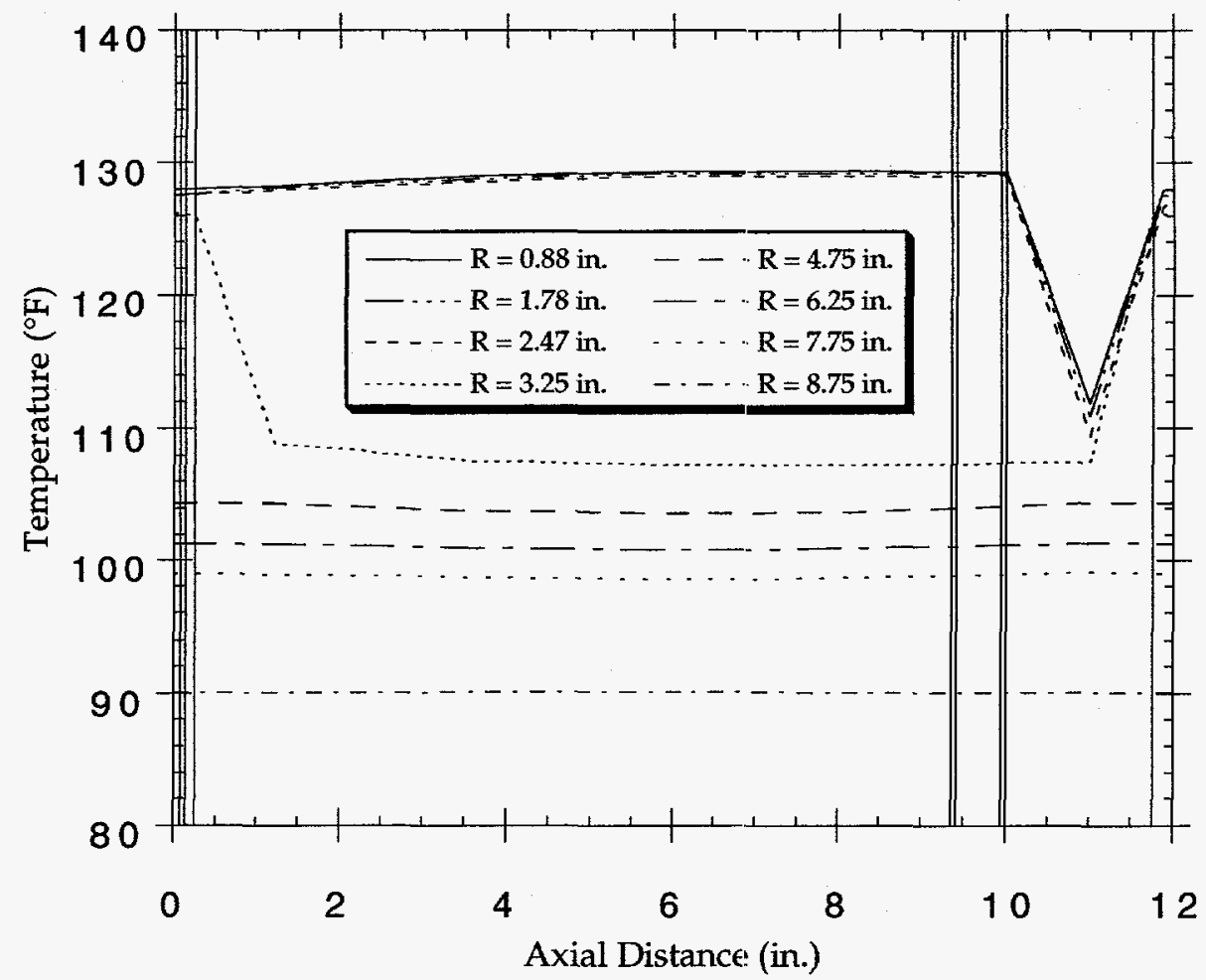

Fig. 15. Axial temperature profiles evaluated by TSAP for the CFX drywell model with $\mathrm{T}(\mathrm{z})_{\mathrm{Air}, \mathrm{BC}}=80^{\circ} \mathrm{F}$. 


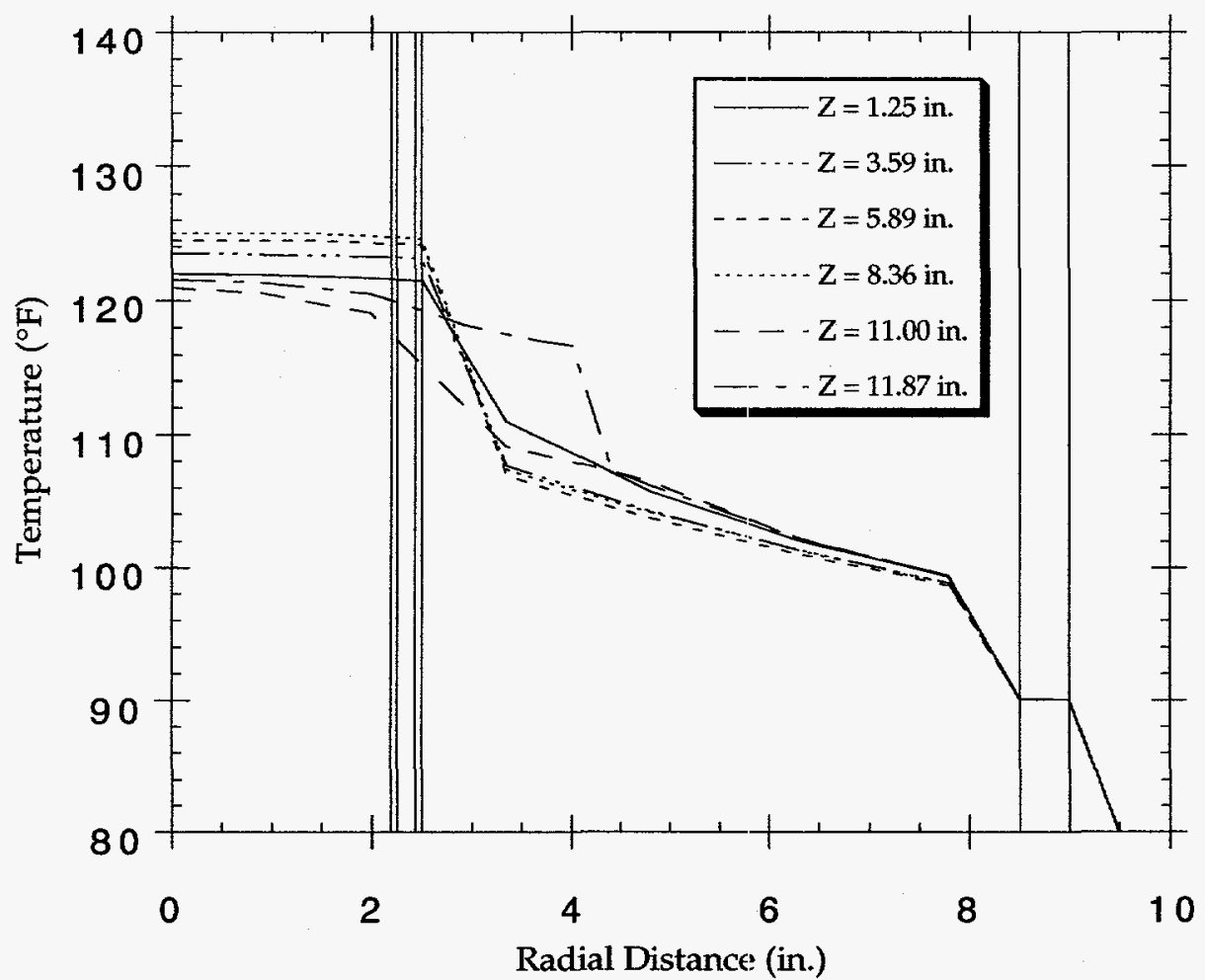

Fig. 16. Radial temperature profiles evaluated by TSAP with adjustment for the CFX drywell model with $\mathrm{T}(\mathrm{z})_{\mathrm{Air}, \mathrm{BC}}=80^{\circ} \mathrm{F}$.

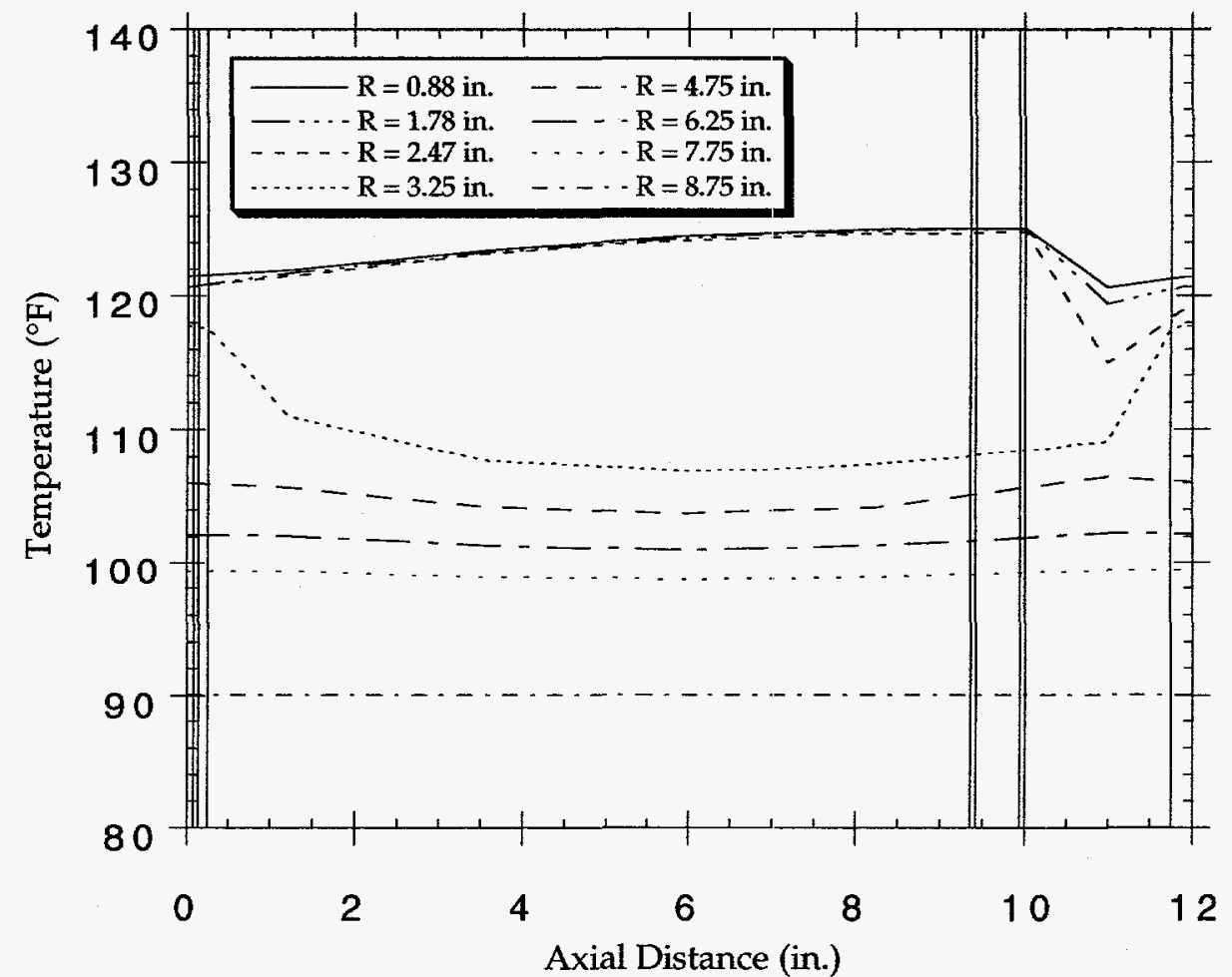

Fig. 17. Axial temperature profiles evaluated by TSAP with adjustment for the CFX drywell model with $\mathrm{T}(\mathrm{z}) \mathrm{Air}, \mathrm{BC}=80^{\circ} \mathrm{F}$. 


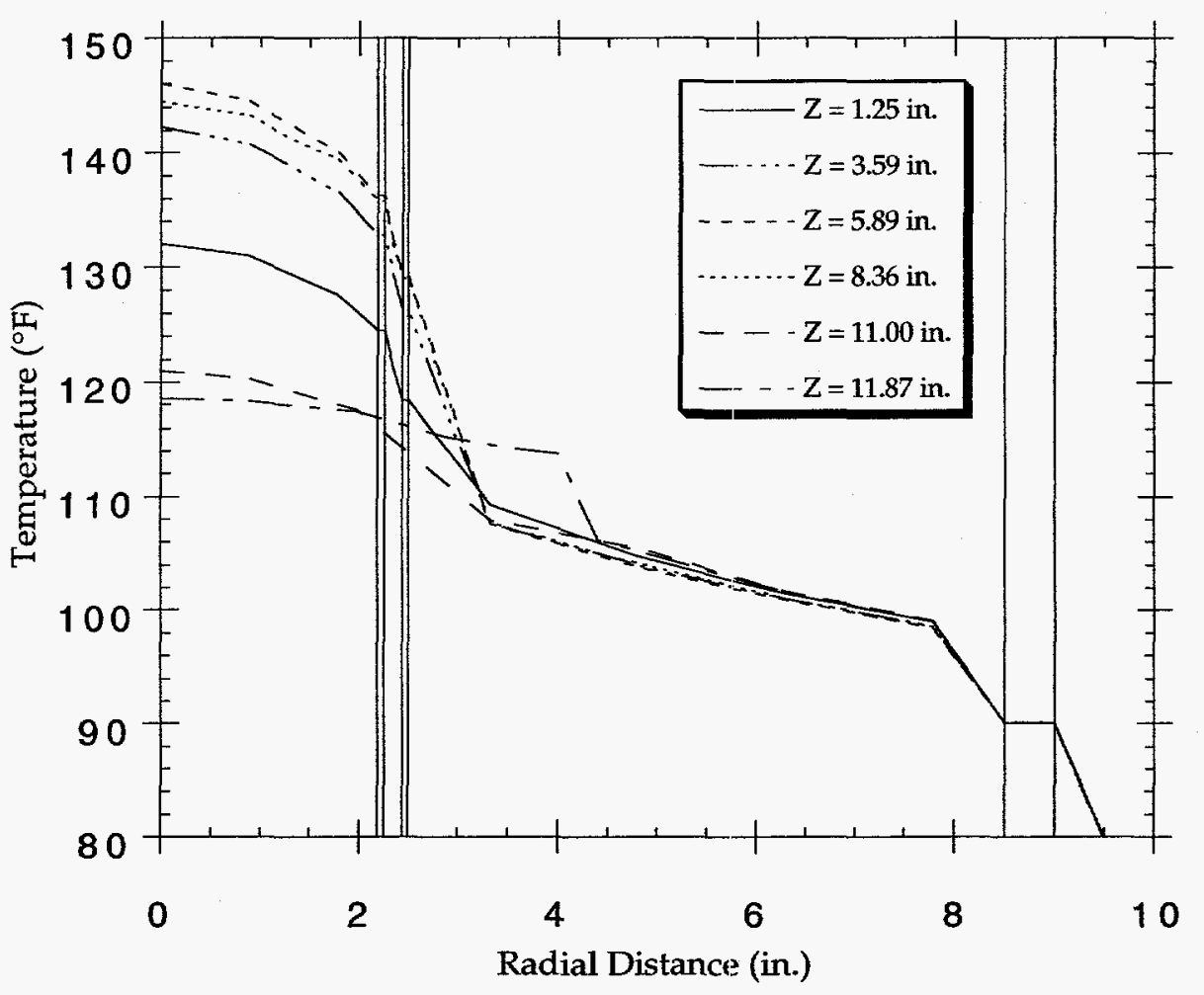

Fig. 18. Radial temperature profiles evaluated by TSAP for the CFX drywell model with $\mathrm{T}(\mathrm{z})_{\mathrm{Air}, \mathrm{BC}}=80^{\circ} \mathrm{F}$ and the plutonium-helium mixture.

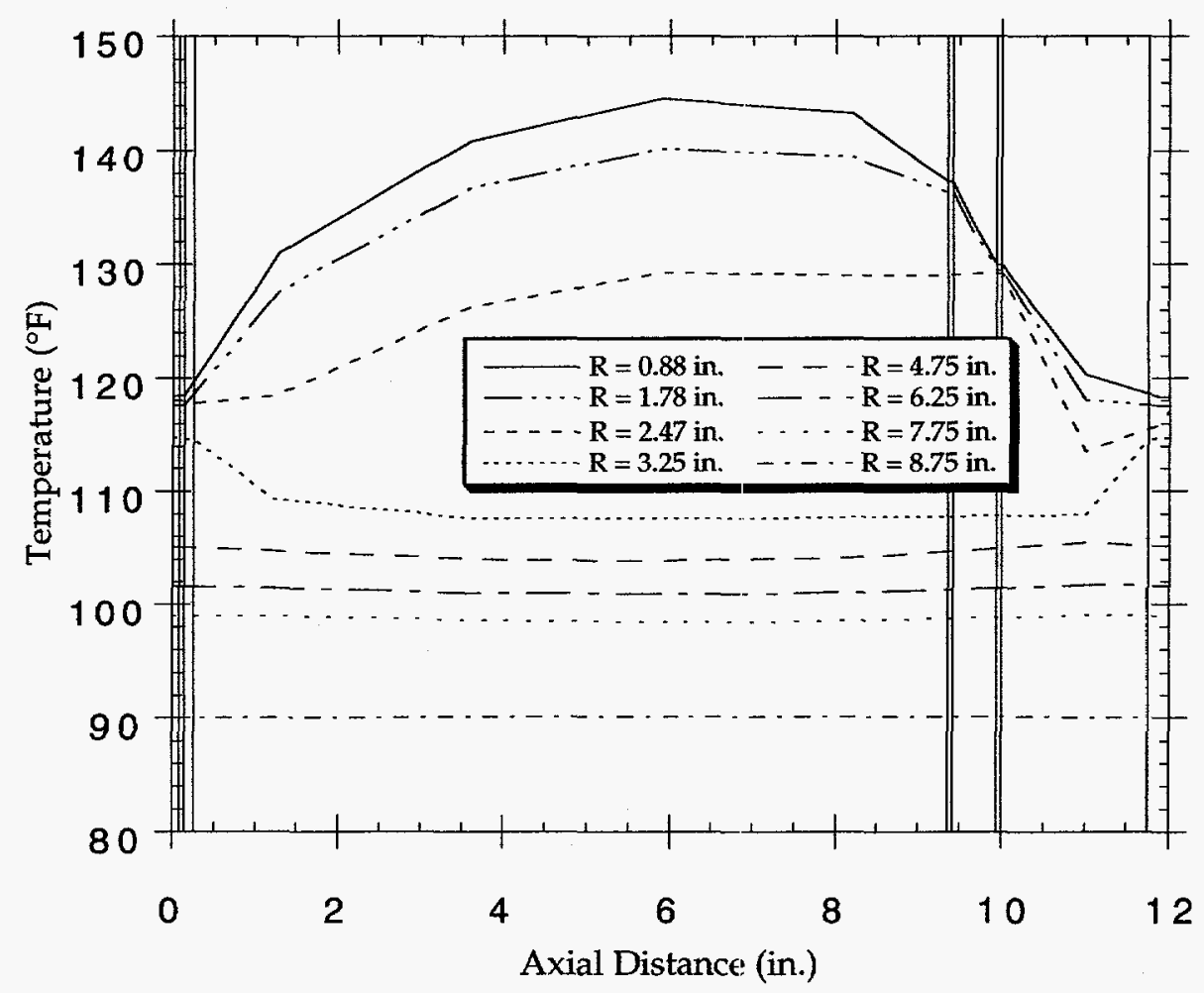

Fig. 19. Axial temperature profiles evaluated by TSAP for the CFX drywell model with $\mathrm{T}(\mathrm{z})_{\mathrm{Air}, \mathrm{BC}}=80^{\circ} \mathrm{F}$ and the plutonium-helium mixture. 